Prepared in cooperation with the High Country Conservancy and Rancho California Water District

\title{
Aquifer Geometry, Lithology, and Water Levels in the Anza- Terwilliger Area-2013, Riverside and San Diego Counties, California
}

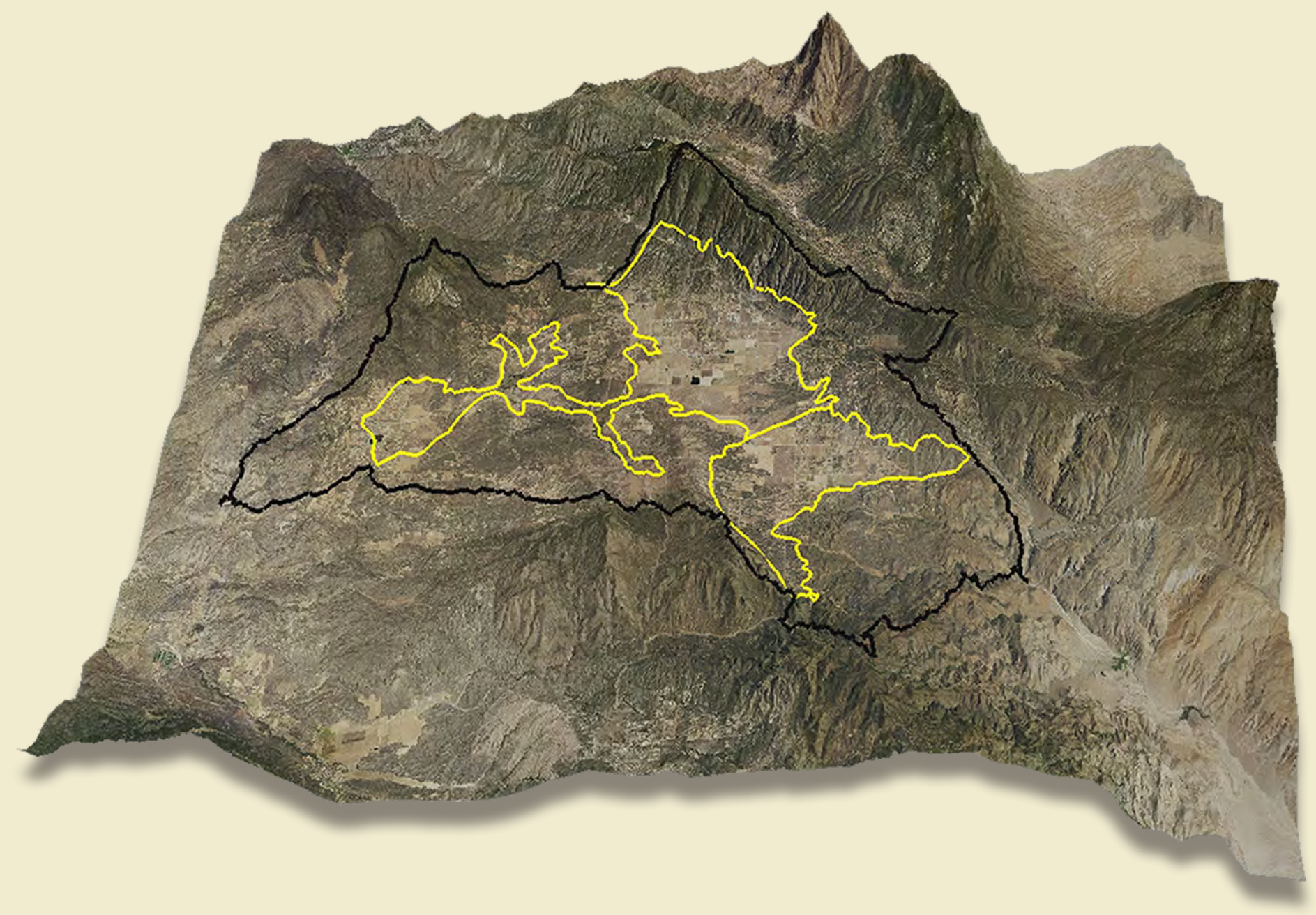

Scientific Investigations Report 2015-5131 
Cover. Aquifer geometry and study unit boundaries for the Anza-Terwilliger area draped over a vertically-exaggerated three-dimensional image created using U.S. Geological Survey National Elevation Dataset, U.S. Department of Agriculture National Agriculture Imagery Program (2014) and ESRI ArcScene. Image by Andrew Morita. 


\section{Aquifer Geometry, Lithology, and Water Levels in the Anza-Terwilliger Area- 2013, Riverside and San Diego Counties, California}

By Matthew K. Landon, Andrew Y. Morita, Joseph M. Nawikas,

Allen H. Christensen, Claudia C. Faunt, and Victoria E. Langenheim

Prepared in cooperation with the High Country Conservancy and Rancho

California Water District

Scientific Investigations Report 2015-5131 


\title{
U.S. Department of the Interior SALLY JEWELL, Secretary
}

\section{U.S. Geological Survey \\ Suzette M. Kimball, Acting Director}

\author{
U.S. Geological Survey, Reston, Virginia: 2015
}

For more information on the USGS - the Federal source for science about the Earth, its natural and living resources, natural hazards, and the environment—visit http://www.usgs.gov or call 1-888-ASK-USGS.

For an overview of USGS information products, including maps, imagery, and publications, visit http://www.usgs.gov/pubprod/.

Any use of trade, firm, or product names is for descriptive purposes only and does not imply endorsement by the U.S. Government.

Although this information product, for the most part, is in the public domain, it also may contain copyrighted materials as noted in the text. Permission to reproduce copyrighted items must be secured from the copyright owner.

Suggested citation:

Landon, M.K., Morita, A.Y., Nawikas, J.M., Christensen, A.H., Faunt, C.C., and Langenheim, V.E., 2015, Aquifer geometry, lithology, and water levels in the Anza-Terwilliger Area-2013, Riverside and San Diego Counties, California: U.S. Geological Survey Scientific Investigations Report 2015-5131, 30 p. http://dx.doi.org/10.3133/sir20155131.

ISSN 2328-0328 (online) 


\section{Acknowledgments}

This study was done in cooperation with the High Country Conservancy and Rancho California Water District. The study was funded through a California Department of Water Resources grant to the Integrated Regional Water Management plan for the Santa Margarita River watershed administered by the Rancho California Water District. In addition, this study was made possible by well and land owners who provided permission to access their property and collect groundwater-level measurements in their wells.

\section{Contents}

Acknowledgments .................................................................................................................ii

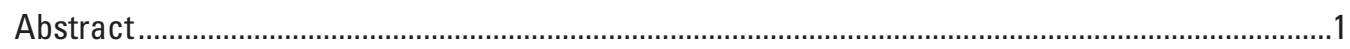

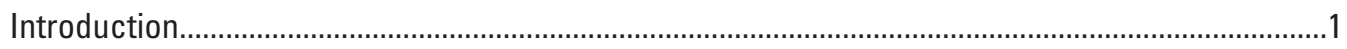

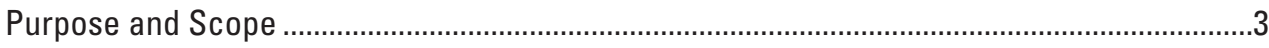

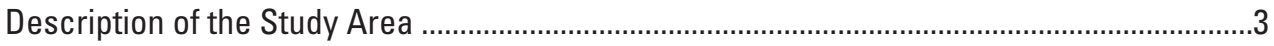

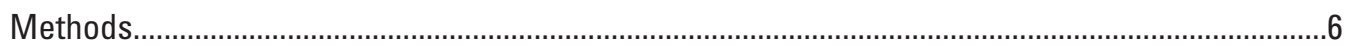

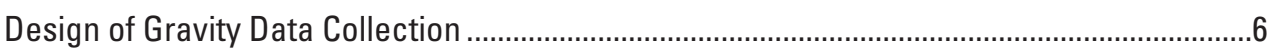

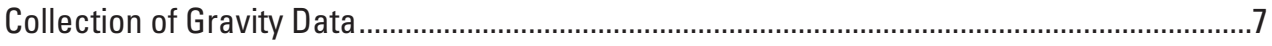

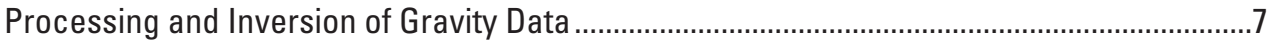

Compilation and Analysis of Lithology ...................................................................................

Collection of Groundwater Level Data ................................................................................11

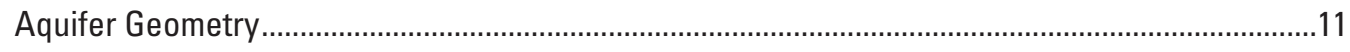

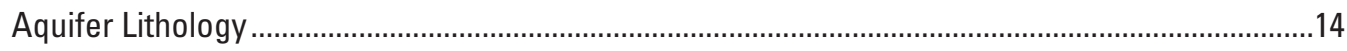

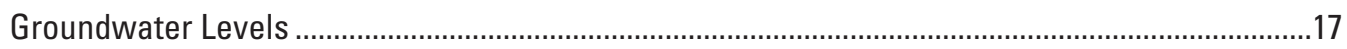

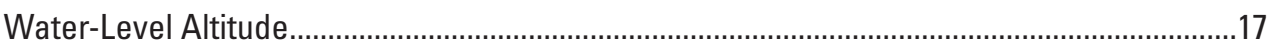

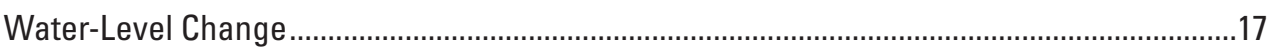

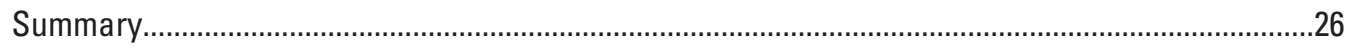

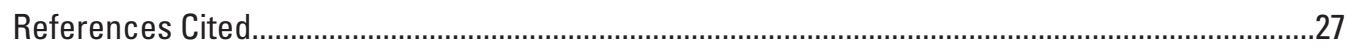

Appendix 1: Identification and Construction Information for Selected Wells in the Anza-Terwilliger Area, Riverside County, California..........................................................30

Appendix 2: Historical Water Levels in the Anza-Terwilliger Area, Riverside County,

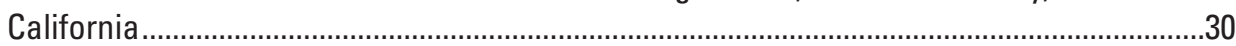

Appendix 3: Fall 2013 Water Levels in the Anza-Terwilliger Area, Riverside County, California.

Appendix 4: Change in Water Level Altitude in Fall 2013, 2006, and 2004 in the Anza-Terwilliger Area, Riverside County, California 


\section{Figures}

1. Map showing location of the Anza-Terwilliger study area, Riverside and San Diego Counties, California

2. Map showing the generalized surface geology of the Anza-Terwilliger study area, Riverside and San Diego Counties, California

3. Map showing the location of $\mathbf{2 0 1 3}$ and previously collected gravity data in the Anza-Terwilliger study area, Riverside and San Diego Counties, California

4. Map showing the distribution of lithology encountered in drillers' logs, including bedrock only, alluvium only, and alluvium overlying bedrock (well extended into bedrock) in the Anza-Terwilliger study area, Riverside and San Diego Counties, California

5. Map showing the isostatic residual gravity field in the Anza-Terwilliger study area, Riverside and San Diego Counties, California

6. Map showing alluvial thickness based on modeled gravity data and drillers' logs in the Anza-Terwilliger study area, Riverside and San Diego Counties, California

7. Diagrams showing the spatial distribution of lithologic categories in the Anza-Terwilliger study area, Riverside and San Diego Counties, California: $A$, lithology of the alluvium draped over the bedrock surface; $B$, lithology of the alluvium and boreholes.

8. Map showing groundwater-level altitude for October-December 2013, Riverside and San Diego Counties, California

9. Map showing change in groundwater altitude from fall 2006 to fall 2013 , Riverside and San Diego Counties, California

10. Map showing change in groundwater altitude from fall 2004 to fall 2013 , Riverside and San Diego Counties, California

11. Graphs showing relative changes in groundwater levels, 1950-2013, Riverside and San Diego Counties, California

\section{Tables}

1. Lithologic categories used in classifying lithologic descriptions in drillers' logs 10 


\title{
Conversion Factors
}

Inch/Pound to International System of Units

\begin{tabular}{|c|c|c|}
\hline Multiply & By & To obtain \\
\hline \multicolumn{3}{|c|}{ Length } \\
\hline inch (in.) & 2.54 & centimeter $(\mathrm{cm})$ \\
\hline inch (in.) & 25.4 & millimeter $(\mathrm{mm})$ \\
\hline foot $(\mathrm{ft})$ & 0.3048 & meter $(\mathrm{m})$ \\
\hline mile (mi) & 1.609 & kilometer $(\mathrm{km})$ \\
\hline \multicolumn{3}{|c|}{ Area } \\
\hline square mile $\left(\mathrm{mi}^{2}\right)$ & 259.0 & hectare (ha) \\
\hline square mile $\left(\mathrm{mi}^{2}\right)$ & 2.590 & square kilometer $\left(\mathrm{km}^{2}\right)$ \\
\hline \multicolumn{3}{|c|}{ Flow rate } \\
\hline foot per year (ft/yr) & 0.3048 & meter per year (m/yr) \\
\hline \multicolumn{3}{|c|}{ Density } \\
\hline pound per cubic foot $\left(\mathrm{lb} / \mathrm{ft}^{3}\right)$ & 16.02 & kilogram per cubic meter $\left(\mathrm{kg} / \mathrm{m}^{3}\right)$ \\
\hline
\end{tabular}

\section{Datum}

Vertical coordinate information is referenced to the North American Vertical Datum of 1988 (NAVD 88)].

Altitude, as used in this report, refers to distance above the vertical datum.

\section{Abbreviations}

\author{
3-D three-dimensional \\ DWR Department of Water Resources \\ GPS Global Positioning System \\ IRWM Integrated Regional Water Management \\ NWIS National Water Information System \\ RTK Real Time Kinematic \\ THCC the High Country Conservancy \\ USGS U.S. Geological Survey
}




\title{
Aquifer Geometry, Lithology, and Water Levels in the Anza-Terwilliger Area-2013, Riverside and San Diego Counties, California
}

\author{
By Matthew K. Landon, Andrew Y. Morita, Joseph M. Nawikas, Allen H. Christensen, Claudia C. Faunt, and \\ Victoria E. Langenheim
}

\section{Abstract}

The population of the Anza-Terwilliger area relies solely on groundwater pumped from the alluvial deposits and surrounding bedrock formations for water supply. The size, characteristics, and current conditions of the aquifer system in the Anza-Terwilliger area are poorly understood, however. In response to these concerns, the U.S. Geological Survey, in cooperation with the High Country Conservancy and Rancho California Water District, undertook a study to (1) improve mapping of groundwater basin geometry and lithology and (2) to resume groundwater-level monitoring last done during 2004-07 in the Anza-Terwilliger area.

Inversion of gravity data, including new data collected for this study, was done to estimate the thickness of the alluvial deposits that form the Cahuilla and Terwilliger groundwater basins and to understand the geometry of the underlying basement complex. After processing of the gravity data, the thickness of the alluvial aquifer materials was modeled by using all available lithology, density, and geophysical data.

The thickest alluvial deposits (greater than 500 feet) are in the northern part of the study area along the south side of the San Jacinto fault zone, in the southern part of the Cahuilla groundwater basin, and in the western part of the Terwilliger groundwater basin. Through most of the area of alluvial materials, the thickness of the alluvium estimated from gravity data is less than 400 feet.

Analysis of more than 900 drillers' logs indicated that in areas having relatively thick alluvium, particularly along the San Jacinto fault zone and in the Terwilliger Valley, the alluvium is predominantly composed of sands and gravels. Fine-textured sediments appeared to be discontinuous rather than forming laterally extensive, low-permeability layers. More than 500 drillers' logs indicated only bedrock is present, indicating that the fractured bedrock is an important source of groundwater, primarily for domestic use, in the study area. The depths of the holes drilled into the bedrock indicated that fractures potentially supplying water to wells persist in the upper few hundred feet and that the permeable zone of the fractured bedrock extends to depths greater than weathered zones in the upper part of the basement complex.

Water-level data were collected from 59 wells during fall 2013. These data indicated that hydraulic head did not vary substantially with well depth and that the measured water levels in bedrock and alluvium were similar. Large offsets in groundwater altitude across the San Jacinto fault zone indicated that the fault zone is a barrier to groundwater flow in the northeastern part of the Anza Valley.

On the basis of data from 33 wells, water levels mostly declined between the fall of 2006 and the fall of 2013; the median decline was 5.1 feet during this period, for a median rate of decline of about 0.7 feet/year. Based on data from 40 wells, water-level changes between fall 2004 and fall 2013 were variable in magnitude and trend, but had a median decline of 2.4 feet and a median rate of decline of about 0.3 feet/ year. These differences in apparent rates of groundwater-level change highlight the value of ongoing water-level measurements to distinguish decadal, or longer term, trends in groundwater storage often associated with climatic variability and trends. Fifty-four long-term hydrographs indicated the sensitivity of groundwater levels to climatic conditions; they also showed a general decline in water levels across the study area since 1986 and, in some cases, dating back to the 1950 s.

\section{Introduction}

The Anza and Terwilliger Valleys, in Riverside County, California, are approximately 20 miles southeast of Hemet and 35 miles southwest of Palm Springs (fig. 1). The population of the Anza and Terwilliger area relies solely on groundwater pumped from the alluvium and surrounding and underlying bedrock formations for water supply (Moyle, 1976; Woolfenden and Bright, 1988). Urban and agricultural land and water use have increased historically in the AnzaTerwilliger area. The size, characteristics, and current conditions of the aquifer system in the Anza-Terwilliger 
area are poorly understood, however. A better understanding of these aspects of the aquifer system would allow water managers in the area to develop groundwater management and monitoring plans and to make informed future management decisions regarding water resources in this growing region.

Local water-management entities and citizens' groups have compiled existing hydrologic information, including from U.S. Geological Survey (USGS) studies in the 1970s (Moyle, 1976), 1980s (Woolfenden and Bright, 1988), and 2000s (Morita and others, 2007a; 2007b), in preparation for developing a groundwater-management plan for the groundwater basin (Anza Groundwater Association, https://sites.google.com/site/anzawatermgt/home). In 2013, the High Country Conservancy (THCC), a non-profit group, was awarded funds through the California Department of Water Resources (DWR) Integrated Regional Water Management (IRWM) plan for the Santa Margarita River watershed, which includes part of the Anza-Terwilliger area, to carry out a study of groundwater resources. The THCC worked with the Rancho California Water District (RCWD), which administers the IRWM plan grants for the Santa Margarita River watershed, to implement the study. The USGS, in cooperation with the RCWD and THCC, did selected technical groundwater assessment tasks, described later, to advance the state of understanding of the groundwater system of the Anza-Terwilliger area. The USGS carried out this work from July 2013 through May 2014.

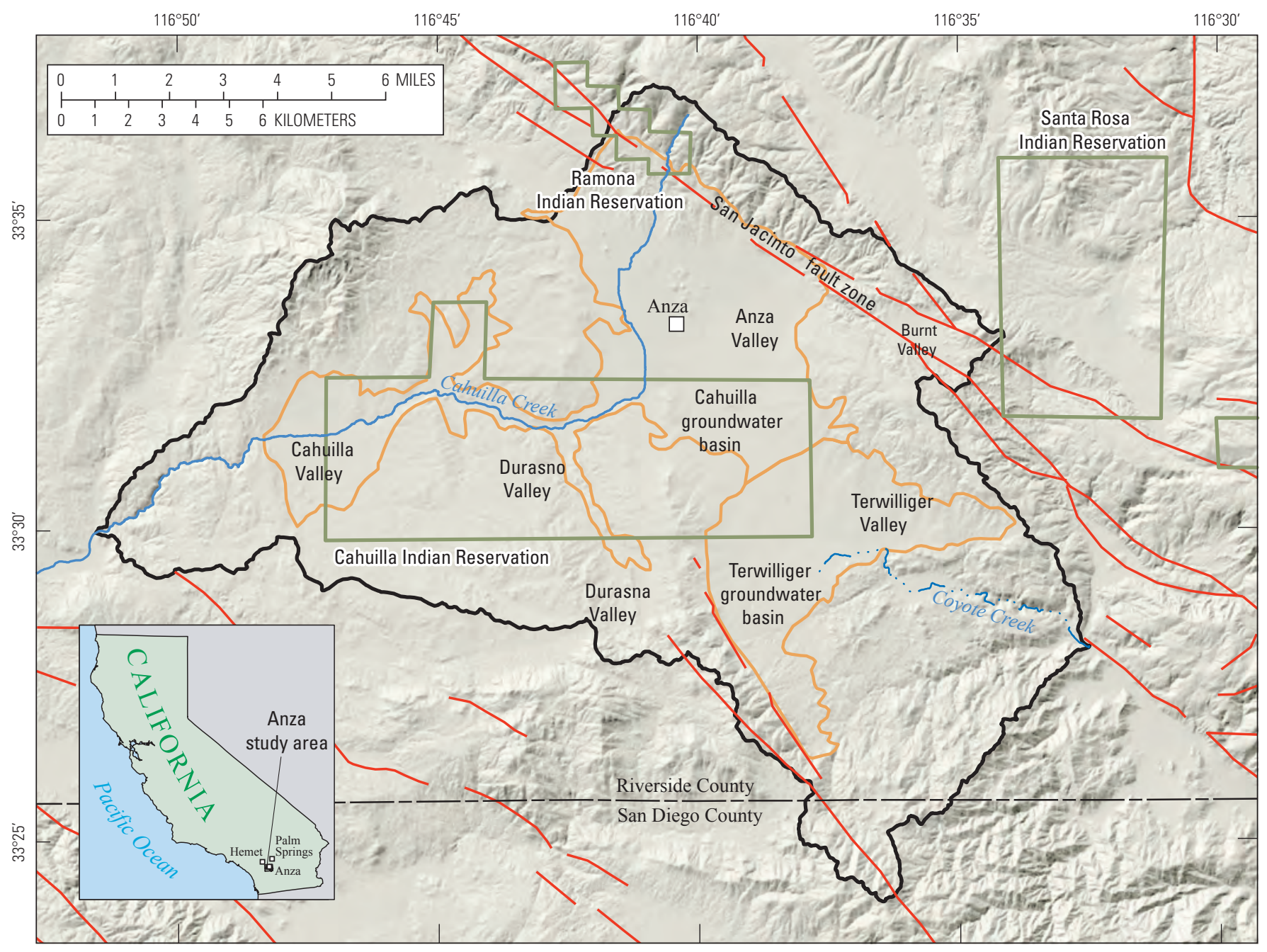

Base from U.S. Geological Survey digital data, 1:100,000, 1981-89; Universal Transverse Mercator Projection, Zone 11.

\section{EXPLANATION}

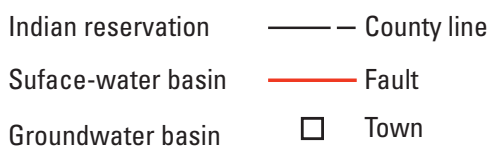

Figure 1. Location of the Anza-Terwilliger study area, Riverside and San Diego Counties, California. 


\section{Purpose and Scope}

The objectives of the Anza-Terwilliger groundwater study were (1) to better define groundwater basin geometry and lithology, (2) to continue groundwater-level monitoring last done during 2004-07, (3) to collect new data to understand vertical variability in water quality better, and (4) to analyze new information in conjunction with previously published information to refine understanding of the groundwater system in the study area.

The purpose of this report is to describe the methods used and the results of analyses of the groundwater basin geometry and lithology and groundwater levels, including newly collected and historical data. Results of groundwater-quality analyses for this study are not discussed in this report, but the data are publicly available from the USGS National Water Information System (NWIS) database (http://waterdata.usgs. gov/nwis).

The scope of this report includes (1) a description of the study area; (2) the methods used for collecting and analyzing gravity data to estimate the thickness of the alluvial aquifer, for compiling and analyzing data on aquifer lithology, and for collecting groundwater-level data; and (3) the results of analyses to determine alluvial aquifer thickness and basin geometry, aquifer texture, and changes in groundwater levels from 2004 and 2006 to October-November 2013.

\section{Description of the Study Area}

The Anza and Terwilliger Valleys are in Riverside County, California, approximately 20 miles (mi) southeast of Hemet and 35 miles southwest of Palm Springs. Because the groundwater system in the Anza and Terwilliger Valleys is recharged by surface-water runoff from the surrounding watershed and is not limited to alluvial aquifer boundaries, the study area was delineated by using the boundaries of the surface-water drainages (hydrologic units) that include the Anza and Terwilliger Valleys (fig. 1). These hydrologic units include the Upper Cahuilla Creek, Lower Cahuilla Creek, and Nance Canyon hydrologic units; the hydrologic unit boundaries were downloaded from the Watershed Boundary Dataset (http://nhd.usgs.gov/wbd.html). The study area is in the upper part of the Santa Margarita River and Coyote Creek watersheds; the Cahuilla Creek hydrologic units drain to the west to the Santa Margarita River watershed and then to the Pacific Ocean; the Coyote Creek hydrologic unit drains to the southeast to the closed interior basin of Borrego (not shown, approximately 25 miles southeast of Anza). The study area is approximately 125 square miles $\left(\mathrm{mi}^{2}\right)$ and includes Anza, Burnt, Cahuilla, Durasna, Durasno, and Terwilliger Valleys and the Cahuilla Indian Reservation (fig. 1). The study area includes two groundwater basins delineated by DWR - the Cahuilla and the Terwilliger groundwater basins (California Department of Water Resources, 2004a, 2004b).
The groundwater basins are defined by the boundaries of unconsolidated alluvial deposits, except where the basins meet along a low topographic divide in the alluvial valley.

The study area has a mean altitude of approximately 3,920 feet ( $\mathrm{ft}$ ) and is in a semi-arid region; this area typically has warm summer days, cold winter temperatures, and occasional snow. The average annual precipitation reported for Anza during 1981-2010 was 11.8 inches (in.); the wettest months are November through April, and infrequent monsoonal storms occur in late summer (Western Regional Climate Center, 2013, http://www.wrcc.dri.edu/).

The resident population of the Anza and Terwilliger area was 3,014 in 2010 (U.S. Census Bureau, 2013). The population was 2,311 in 2000 , indicating a 30 percent increase during $2000-10$. The population is widely distributed in lowdensity housing across the valleys in the study area.

Land-use maps from 2000 showed this area was (and still is) mostly covered with native vegetation and was lightly urbanized with residences and small businesses (California Department of Water Resources, 2007). Local agriculture includes farmsteads and livestock feedlots, grain and hay crops including barley, wheat, oats, miscellaneous mixed grains, hay, and pasture; some areas are classified as mixed pasture along with alfalfa and alfalfa mixtures. There are small acreages of truck nursery, berry crops, and potatoes in the area. There were also small areas of idle land identified on the 2000 maps that had either been harvested or were awaiting future crop production.

The Anza and Terwilliger area is drained by two ephemeral creeks, Cahuilla Creek near Anza and Coyote Creek near the southeastern part of the Terwilliger basin. Anza, Burnt, Cahuilla, Durasna, and Durasno Valleys are drained by Cahuilla Creek, which flows toward the west and eventually drains into the Pacific Ocean. Terwilliger Valley, in the southeastern part of the study area, is drained by Coyote Creek toward Borrego Springs and into the Salton Sea. The Cahuilla Indian Reservation is in the center of the study area and extends into both drainages. Although the water table historically has been near the land surface in some areas along Cahuilla Creek in the lower Cahuilla Valley, Cahuilla Creek is not perennial in the study area (Moyle, 1976).

The geology of the study area includes basement rocks and unconsolidated to weakly consolidated alluvial sediments (Rogers, 1965; Dibblee and Minch, 2008); both types of geologic materials serve as aquifers in the study area. Geologic descriptions of units are primarily based upon the more recent geologic map of Dibblee and Minch (2008). This map did not include the southern third of the study area, however. Consequently, the older map of Rogers (1965) was used as the geologic base map for this study (fig. 2). The Dibblee and Minch (2008) and Rogers (1965) maps are in general agreement concerning the spatial distribution of principal geologic units. 


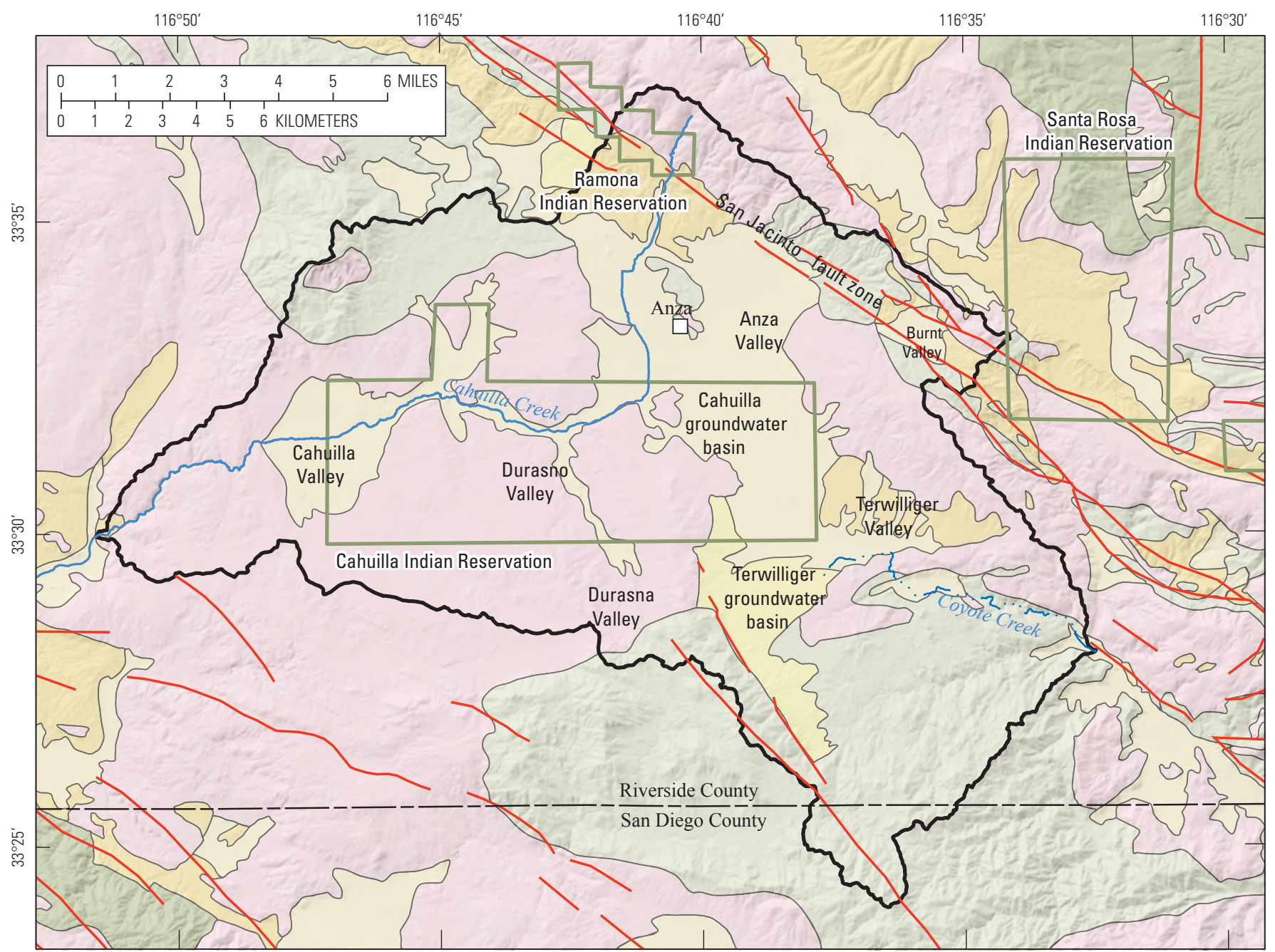

Base from U.S. Geological Survey digital data, 1:100,000, 1981-89; Universal Transverse Mercator Projection, Zone 11.

\section{EXPLANATION}

\section{Geologic Type/Age}

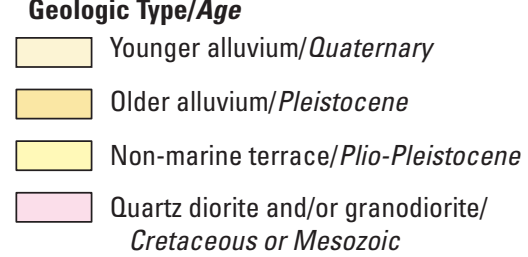
Cretaceous or Mesozoic

Metasediments (schist)/Paleozoic or Mesozoic

Other metasediments/Paleozoic or Mesozoic

Figure 2. Generalized surface geology of the Anza-Terwilliger study area, Riverside and San Diego Counties, California (modified from Rogers, 1965). 
The primary basement rocks in most of the study area (southern and central) are Cretaceous quartz diorite to granodiorite, but include granite, diorite, and tonalite (Dibblee and Minch, 2008). This unit crops out in upland areas surrounding the alluvium in the study area, except along parts of the northern and southern boundaries of the study area (fig. 2). On the basis of drillers' logs, this unit also is present beneath large areas of the alluvial deposits.

In the southern and northern parts of the study area, the predominant basement rocks are Paleozoic or Mesozoic metasedimentary rocks, primarily dark gray, fine-grained schist ranging to diorite gneiss, hornblende schist, and mica schist (Dibblee and Minch, 2008). This unit crops out in upland areas on northwest and north-central parts of the Anza Valley and on the south side of the Terwilliger Valley (fig. 2). This unit also is present beneath alluvial deposits in the northcentral part of the Anza Valley.

Dibblee and Minch (2008) also mapped small areas of gabbro and quartz monzonite in the southwestern and northeastern parts of the study area. However, the footprints of these units are small, and the units have no effect on the hydrogeology of the study area.

Where weathered or fractured, the basement rocks can yield small to moderate amounts of water (Moyle, 1976; Woolfenden and Bright, 1988). Many domestic and some irrigation wells are drilled into the basement rock in the outcrop areas near the alluvial valleys. In addition, some wells in alluvial areas are drilled into the underlying bedrock and are perforated in both lithologies. In addition to a weathered zone reported near the top of the bedrock (Moyle, 1976; Woolfenden and Bright, 1988), the granitic and metasedimentary rock units appear to be heavily fractured and widely used for domestic supply wells. The extensive fracturing is likely the consequence of the active tectonic setting of the study area and proximity to the San Jacinto fault zone in the northeastern part of the study area (fig. 2). The San Jacinto fault zone, consisting of multiple strands in the study area, is a major regional fault system that is part of the broader San Andreas fault system that serves as a boundary between the Pacific and North American plates (Matti and Morton, 1993).

Quaternary alluvial deposits in valley areas include younger (Holocene and Pleistocene) sediments and older (early Pleistocene and Pliocene) semi-consolidated alluvial deposits that crop out in terraces near the edges of the alluvial valleys and underlie the younger alluvium (fig. 2). The younger alluvium is composed of unconsolidated boulders, gravel, sand, silt, and thin clay (Moyle, 1976). The younger alluvium is generally unsaturated and above the regional water table in the study area (Moyle, 1976). Younger alluvium crops out in the western Cahuilla Valley, central Burnt Valley, Durasna and Durasno Valleys to the south, the center of the study area, and along Cahuilla and Coyote Creeks (fig. 2).

The older alluvium consists of weakly indurated (poorly consolidated) gravel, boulders, sand, silt, and clay. The older alluvium primarily crops out in the Terwilliger Valley, with smaller outcrops in Burnt Valley to the east and in the northeastern Anza Valley near the San Jacinto fault zone. In addition, older alluvium includes weakly indurated alluvial sandstone and alluvial fan sediments of Plio-Pleistocene age (mapped as Non-marine terrace on fig. 2). These PlioPleistocene deposits are in the southern part of the Terwilliger Valley and in the northwestern part of the study area along the San Jacinto fault zone (fig. 2).

The thickness of the alluvial deposits was estimated in parts of the study area by Moyle (1976; fig. 3) on the basis of limited drillers' log data and gravity data. These preliminary interpretations were not well constrained because of limited information; consequently, a Bouguer gravity anomaly map was published by Moyle (1976) rather than a fully interpreted alluvial thickness model. The results of the preliminary analysis indicated that the alluvial deposits were thickest in the southern Anza and northern Terwilliger Valleys and in the northeastern Anza Valley near the San Jacinto fault zone.

The groundwater system in the basement rocks and alluvial deposits is generally considered to be unconfined (Moyle, 1976; Woolfenden and Bright, 1988). For the purposes of adjudicating water rights in the Santa Margarita River watershed in the early 1960s, however, groundwater in the Anza Valley was divided into shallow and deep aquifers; the deep aquifer was classified as not contributing to the Santa Margarita River watershed (Binder, 2012). The location of the deep aquifer and confined conditions has not been systematically mapped. Based upon maps of groundwater altitude representing the summers of 1973 (Moyle, 1976) and 1986 (Woolfenden and Bright, 1988), groundwater generally flows from the upland areas surrounding the valleys toward the valley centers, which is generally from east to west, following the regional topographic slope. 


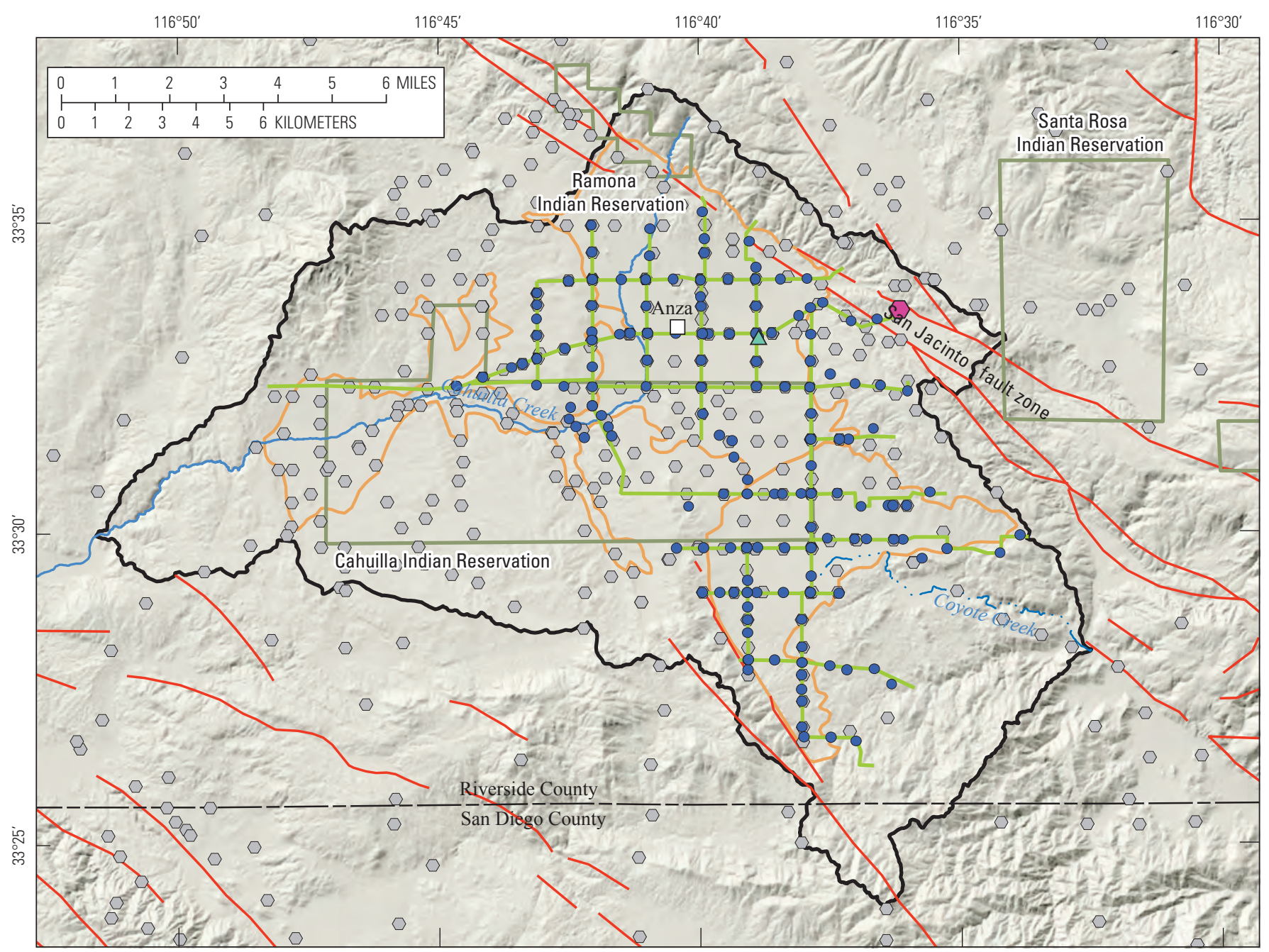

Base from U.S. Geological Survey digital data, 1:100,000, 1981-89;

Universal Transverse Mercator Projection, Zone 11.

\section{EXPLANATION}

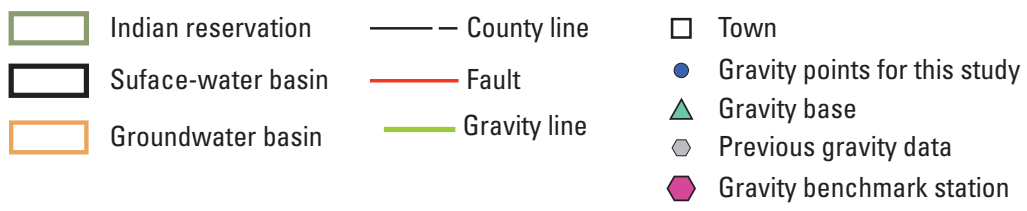

Figure 3. Location of 2013 and previously collected gravity data in the Anza-Terwilliger study area, Riverside and San Diego Counties, California.

\section{Methods}

\section{Design of Gravity Data Collection}

Gravity data were used to estimate the thickness of the alluvial deposits that form the Cahuilla and Terwilliger groundwater basins (California Department of Water Resources, 2004a, 2004b) and to help understand the threedimensional (3-D) geometry of the underlying basement rock. Existing and new gravity measurements and drillers' logs from water wells and test holes (see "Compilation and Analysis of Lithology"), were the primary data sets used to estimate the thickness and geometry of the alluvial groundwater basins. There is a large density contrast between the alluvium and the basement rocks, making the depth to basement rocks a good target for study by gravity methods. Aeromagnetic data also were examined to help define the magnetic characteristics of the basement rocks (Jachens, 1992, 1993). Lithologic logs from wells in the study area that penetrated bedrock were used to help verify and calibrate inversion of the gravity data to determine the approximate depth to basement and the alluvial thickness. Geologic maps were used to define the contact of the basement rocks and alluvial deposits at land surface (Rogers, 1965; Dibblee and Minch, 2008; Landcaster and others, 2012). 


\section{Collection of Gravity Data}

Gravity measurements were taken at 170 locations in the Anza and Terwilliger area; these data were combined with about 200 regional gravity measurements (Moyle, 1976; Biehler and others, 1992; Ponce and Langenheim, 1992; Langenheim and Jachens, 1993) to produce a map of the isostatic residual gravity field. Most of the measurements were taken along north-south and east-west transects along roads across Anza and Terwilliger Valleys (fig. 3).

Gravity data were collected by using a LaCoste and Romberg Model D-79 gravity meter with Aliod 100 modification, connected by serial cable to a Trimble Nomad PDA, where the data were stored. The location and altitude of each gravity measurement point was determined by using a Trimble Real Time Kinematic (RTK) Model R7 and R8 Global Positioning System (GPS) base and mobile receivers with Trimble TSC-3 data controllers following the traditional RTK methods described by Morton and others (1993). This system can determine vertical and horizontal coordinates with a precision of plus or minus $0.083 \mathrm{ft}$ between the receiver and a base (reference) station. Raw GPS data were exported and processed by using Trimble Business Center version 2.81 by Trimble Navigation Limited. The location of the reference station was determined by methods described in Rydlund and Densmore (2012) and using static GPS data collected at the base station and uploaded to Online Position User Service (OPUS), National Oceanic and Atmospheric Administration, National Geodetic Survey at http://www.ngs. noaa.gov/OPUS/.

\section{Processing and Inversion of Gravity Data}

Analysis of the gravity data was performed by using standard gravity corrections that include (1) earth tide, (2) instrument drift, (3) latitude and longitude, (4) freeair, (5) Bouguer, (6) curvature, (7) terrain, and (8) isostatic corrections (Telford and others, 1976). Earth-tide corrections take into account tidal effects caused by the sun and moon. Instrument-drift corrections offset any drift created with the instrument's internal spring. Raw-gravity data exported from the Nomad were processed for instrument drift by using GravMaster version 1.43 by Geotools Corporation. Latitude/ longitude corrections take into account the earth's gravity in relation to latitude. Free-air corrections take into account the variances in gravity due to changes in altitude relative to mean sea level. The Bouguer correction takes into account the attraction of materials between the measurement point and sea level. The curvature correction is included with the Bouguer correction to account for curvature of the earth. Terrain corrections account for the effects of topography. Isostatic corrections remove the long-wavelength gravitational effect of isostatic compensation of the crust due to topography.

Accurate altitude data at the gravity measuring point are an important factor in establishing accurate free-air corrections and improving the resolution of the alluvial-bedrock interface. The Trimble RTK system was used because of the poor vertical consistency offered by conventional standalone GPS. The RTK uses radio communication broadcasting real-time correction data from the base-station receiver to adjust for variances to the $\mathrm{X}, \mathrm{Y}$, and $\mathrm{Z}$ coordinates of the rover reference antenna (primarily the $\mathrm{Z}$ or altitude coordinate). Error in the altitudes measured in this study translates to 0.005 milliGals (mGal) error in the gravity anomaly.

All gravity measurements collected during this study were referenced to a primary gravity benchmark station (PB0521, Roberts and Jachens, 1986), which is tied to the International Gravity Standardization Net 1971 (IGSN71) datum. Station PB0521 is approximately 5 miles east of Anza along Highway 371 (fig. 3). This station was selected because it is close to the study area and because it is on bedrock near the topographic divide of the basin, which minimizes the potential effects of mass changes (water-level changes) in the alluvium. Five data-collection loops were completed between station PB0521 and a new local gravity base station that was used as a reference location for repeated measurements through time in the center of the study area (fig. 3). The gravity data collected between the two stations closed to within $0.023 \mathrm{mGal}$, indicating good precision in the measurements. A new local gravity base station was established central to the study area (fig. 3) to minimize travel time and instrument drift during surveys.

Throughout the study area, the thickness of the alluvium was estimated by using the method of Jachens and Moring (1990). The method was modified slightly to allow inclusion of constraints where the thickness of the alluvial deposits was identified directly from drill-hole observations (see "Aquifer Lithology"). A smooth surface through the gravity points collected where basement rocks are exposed at land surface (basement gravity field) was used to generate an initial estimate of the alluvial-fill gravity anomaly by subtracting this surface from the isostatic residual gravity field. Because gravity values collected on the basement complex near alluvium are influenced by lower density alluvial deposits, this represented only an initial estimate. To adjust for this effect, the alluvial gravity anomaly was used to calculate an initial thickness. The gravity effect on the alluvium was then calculated at the basement complex data points. Additional estimates of the basement field were made by passing another smooth surface through the corrected basement data points and adjusting for the alluvial-fill effect. These estimates were processed until notable changes were no longer present in the modeled thickness of alluvium. 
All thickness calculations were made by using gravity values interpolated to a regular grid having nodes spaced about $656 \mathrm{ft}$ (200 meters) apart. The groundwater-basin gravity anomaly was converted into a thickness of the alluvium by using assumed average density differences between alluvium that forms the groundwater basins and the basement complex beneath it. The density contrast varies with depth because density increases with depth; this study used the same density contrast relations used by Martin and others (2011) in a study in the Palm Springs area. Within the upper 200 meters (m), the assumed average density difference was 550 kilograms per cubic meter $\left(\mathrm{kg} / \mathrm{m}^{3}\right)$; from 656 to $1,970 \mathrm{ft}$ (200 to $600 \mathrm{~m}$ ), the assumed average density difference was $360 \mathrm{~kg} / \mathrm{m}^{3}$. The density contrast was calibrated by comparing the results of the modeled groundwater-basin gravity anomaly to the well observations (logs) where they were reported to penetrate the basement complex. With an assumed average density of $2,670 \mathrm{~kg} / \mathrm{m}^{3}$ for the basement rocks in the study area, the density contrast of $550 \mathrm{~kg} / \mathrm{m}^{3}$ between the alluvium and the basement complex indicated a density of $2,120 \mathrm{~kg} / \mathrm{m}^{3}$ for the alluvium in the upper $200 \mathrm{~m}$.

Gravity, geologic maps, and drillers' logs were the primary data sets used to define the thickness of the alluvium. Further investigations were performed to test the gravity field for any local anomalies by using data from drill-log sites where wells penetrated basement. The basement gravity field was compared to the residual magnetic field of the area (Jachens, 1992, 1993), which was mathematically converted to the equivalent of the gravity field (magnetic potential or pseudogravity, Baranov, 1957), because both fields reflect the distribution of basement rock bodies, albeit by different physical properties (density and magnetization). This was done in a qualitative manner to ensure no obvious distortions were present in the basement gravity field that were not also present in the converted magnetic field.

\section{Compilation and Analysis of Lithology}

Information compiled from 946 drillers' logs in or near the study area (fig. 4) was used to analyze the lithology of the Anza-Terwilliger groundwater basins. Most of the drillers' logs were obtained from the DWR. Some logs in the study area were available from the hardcopy or digital files of the USGS San Diego projects office files; these logs were primarily for private water wells drilled more than 50 years ago or on reservations that did not appear in the DWR log inventory. The drillers' logs were the only lithologic data that were available for the study area. Spatial density of available data varied throughout the study region (fig. 4).

The source of location information for each well varied from GPS coordinates to sketched maps or township, range, section, and quarter-quarter-section information on the well-completion reports, and therefore, the accuracy also varied. Wells that had detailed sketched maps were assigned a latitude-longitude location by comparing the maps with aerial photos in a geographic information system (GIS). For wells that lacked detailed sketched maps, but had the township, range, section, and quarter-quarter section information, the location was assumed to be at the center of the quarter-quarter section.

Summary descriptions and depth intervals of each lithology from the available drillers' logs were entered into a database. These data included texture, indicating the primary grain size or rock type of the material (for example, clay, sand, gravel, cobbles, granite, schist, and so on); primary and secondary modifiers (for example, clayey, sandy, and so on); and qualifiers (for example, soft, firm, or consolidated).

Lithologic data from drillers' logs are generally of variable quality, showing a wide range of detail in the lithologic information (Faunt, 2009). These drillers' logs were no exception; lithologic descriptions were highly variable in terms of the number and thickness of subsurface intervals described, the detail of the descriptions, and the words used to describe specific sediment types and textures. The descriptions required geologic interpretation to obtain consistency of methodology among wells and to identify the unit penetrated. Ambiguous or imprecise lithologic descriptions were excluded from the final data set, leaving 68 textural classes for spatial analysis. The lithology data were classified into categories on the basis of texture and sorting by using a similar approach to Faunt (2009; table 1).

Quality-assurance analysis included verifying the location of the log and inspecting the suitability of the lithologic descriptions for understanding lithologic distributions. These evaluations resulted in removal of some logs from the data used. Thereafter, lithology data from drillers' logs were classified and used to map the spatial distribution of lithology in the study area. The borehole data were displayed in 3-D space by using color coding of the lithology classifications. By displaying the data in 3-D, it was possible to visualize more boreholes all at once rather than by looking only at discrete cross sections.

A 3-D geologic framework model was constructed to represent the subsurface geometry of the alluvium and a bedrock unit (specifically, a composite of bedrock units), as well as the lithology of the alluvium. This digital model provides a fundamental geologic framework for subsequent studies in the basin. The geologic framework model was constructed by creating surfaces representing the altitude of the top of the subsurface bedrock and the land surface and, then, combining these surfaces by using a 3-D geologic modeling software package. Each surface was represented by a grid that covered a rectangular area with dimensions of $105,000 \mathrm{ft}(32,000 \mathrm{~m})$ in the east-west direction and $85,300 \mathrm{ft}$ $(26,000 \mathrm{~m})$ in the north-south direction, slightly larger than the study area (surface-water drainage, fig. 1). The square grid cells were $656 \mathrm{ft}(200 \mathrm{~m})$ per side $\left(430,000 \mathrm{ft}^{2} ; 0.0154 \mathrm{mi}^{2}\right.$ in area), resulting in 160 grid cells in the east-west direction and 130 cells in the north-south direction. Software-based requirements for the grids and 3-D model to be aligned with the cardinal directions resulted in the inclusion of areas outside the study area. 


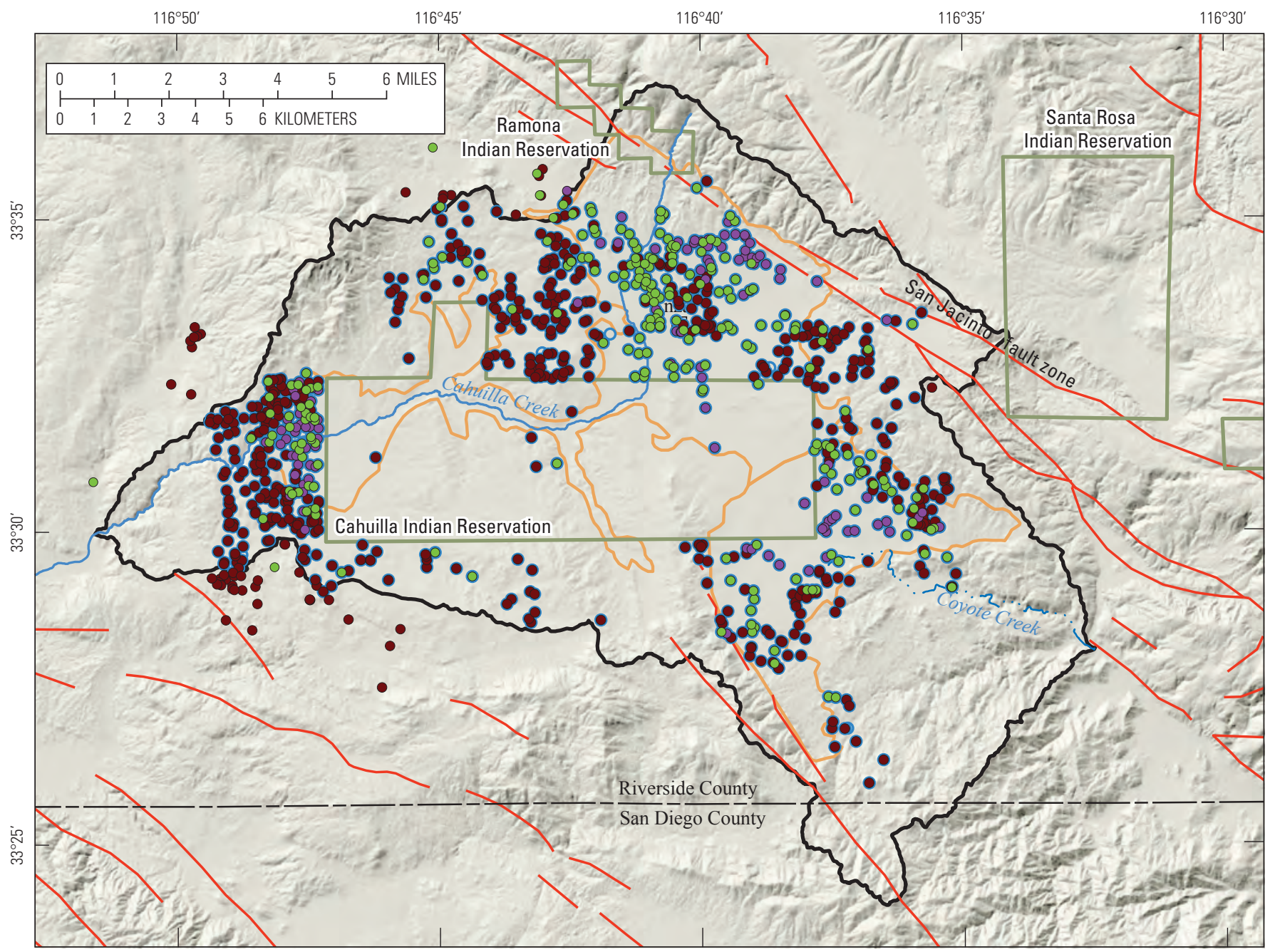

Base from U.S. Geological Survey digital data, 1:100,000, 1981-89; Universal Transverse Mercator Projection, Zone 11.

\section{EXPLANATION}

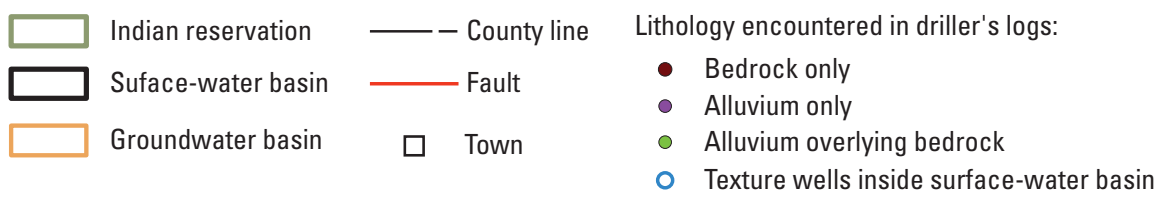

Figure 4. Distribution of lithology encountered in drillers' logs, including bedrock only, alluvium only, and alluvium overlying bedrock (well extended into bedrock) in the Anza-Terwilliger study area, Riverside and San Diego Counties, California.

To construct the geologic framework model, spatial data, such as digital altitude and borehole information, were compiled and interpolated by using Environmental Science Research Institute (ESRI) ArcGIS ${ }^{\circledR}$ software. Grids representing the alluvium and bedrock unit tops were combined and visualized by using Rockware Rockworks $16^{\circledR}$ 3-D-modeling software following the methods of Sweetkind and others (2013), as briefly described in this report. This software was designed to represent stratigraphic relations in sedimentary basins, including representation of depositional contacts and stratigraphic onlap, erosion, and unconformities. Explicit faults were not included in the framework model. In some areas near the edge of the alluvial deposits, map data and limited well data indicated the presence of alluvium, but the well data were too limited and gravity information too imprecise to create a satisfactory thickness-grid, so the alluvium was assigned an arbitrary thickness of $20 \mathrm{ft}$. Finally, in areas of bedrock outcrop, the top of the alluvium was assigned the altitude of land surface and a thickness of zero was specified. By using the cases described above, the altitude grids for the two units (alluvium and bedrock) were built in an iterative fashion. First, the parts of the unit present in the subsurface were gridded using the borehole data. These grids then were modified in areas where the unit cropped out or where underlying units were exposed at land surface. 
Table 1. Lithologic categories used in classifying lithologic descriptions in drillers' logs.

\begin{tabular}{|c|c|c|c|c|c|}
\hline Texture & Sorting & Materials & Texture & Sorting & Materials \\
\hline Top soil & Not applicable & Bouldery top soil & Coarse & Interbedded & Sandy gravel \\
\hline Top soil & Not applicable & Clayey sandy top soil & Coarse & Interbedded & Silty gravel \\
\hline Top soil & Not applicable & Clayey top soil & Medium & Massive & Sand \\
\hline Top soil & Not applicable & Gravelly top soil & Medium & Massive & Sandy loam \\
\hline Top soil & Not applicable & Hard pan & Medium & Massive & Sandy sand \\
\hline Top soil & Not applicable & Sandy top soil & Medium & Interbedded & Bouldery clayey sand \\
\hline Top soil & Not applicable & Silty sandy top soil & Medium & Interbedded & Clayey cobbley sand \\
\hline Top soil & Not applicable & Silty top soil & Medium & Interbedded & Clayey gravelly sand \\
\hline Top soil & Not applicable & Top soil & Medium & Interbedded & Clayey sand \\
\hline Coarse & Massive & Boulders & Medium & Interbedded & Clayey silty sand \\
\hline Coarse & Massive & Bouldery gravel & Medium & Interbedded & Cobbley clayey sand \\
\hline Coarse & Massive & Cobbles & Medium & Interbedded & Gravelly clayey sand \\
\hline Coarse & Massive & Cobbley cobbles & Medium & Interbedded & Sandy clayey sand \\
\hline Coarse & Massive & Cobbley gravel & Medium & Interbedded & Silty clayey sand \\
\hline Coarse & Massive & Gravel & Medium & Interbedded & Silty sand \\
\hline Coarse & Massive & Gravelly gravel & Fine & Massive and interbedded & Sandy silt \\
\hline Coarse & Interbedded & Bouldery sand & Fine & Massive and interbedded & Silt \\
\hline Coarse & Interbedded & Clayey boulders & Fine & Massive and interbedded & Sandy clayey silt \\
\hline Coarse & Interbedded & Clayey cobbles & Very fine & Massive & Clay \\
\hline Coarse & Interbedded & Clayey gravel & Very fine & Massive & Silty clay \\
\hline Coarse & Interbedded & Clayey sandy boulders & Very fine & Interbedded & Bouldery clay \\
\hline Coarse & Interbedded & Clayey sandy cobbles & Very fine & Interbedded & Bouldery sandy clay \\
\hline Coarse & Interbedded & Clayey sandy gravel & Very fine & Interbedded & Cobbley clay \\
\hline Coarse & Interbedded & Clayey silty gravel & Very fine & Interbedded & Cobbley sandy clay \\
\hline Coarse & Interbedded & Cobbley gravelly sand & Very fine & Interbedded & Gravelly clay \\
\hline Coarse & Interbedded & Cobbley sand & Very fine & Interbedded & Gravelly sandy clay \\
\hline Coarse & Interbedded & Cobbley sandy gravel & Very fine & Interbedded & Sandy clay \\
\hline Coarse & Interbedded & Gravelly cobbley sand & Very fine & Interbedded & Sandy gravelly clay \\
\hline Coarse & Interbedded & Gravelly sand & Very fine & Interbedded & Silty sandy clay \\
\hline Coarse & Interbedded & Gravelly sandy sand & Bedrock & Not applicable & Granite \\
\hline Coarse & Interbedded & Sandy boulders & Bedrock & Not applicable & Sandy shale \\
\hline Coarse & Interbedded & Sandy clayey cobbles & Bedrock & Not applicable & Schist \\
\hline Coarse & Interbedded & Sandy clayey gravel & Bedrock & Not applicable & Shale \\
\hline Coarse & Interbedded & Sandy cobbles & Not applicable & Not applicable & Undefined \\
\hline
\end{tabular}

The final 3-D geologic framework was compiled by using the Rockworks 3-D modeling package, which allows individual gridded surfaces to be stacked in stratigraphic order. The thickness of the unit is represented by the difference between altitudes of successive stratigraphic tops, such that the altitude of the base of a unit is always equal to the altitude of the top of the unit directly below it in the stacking order. In this case, only two surfaces were used, the top of the bedrock and land surface, with the intermediate volume representing the alluvium.
An analysis of variability of lithology and grain size was completed for the alluvium. Textural data, such as grain size, sorting, and bedding characteristics, form the geologic basis for estimating the hydraulic properties in a numerical hydrologic-flow model (Burow and others, 2004; Faunt and others, 2010). Textural variability in the alluvium is ultimately a function of the sedimentary facies, environment of deposition, depositional history of the basin, and proximity to faults. 
The interpreted grain-size and sorting parameters derived from the drillers' logs were used to construct a 3-D model of textural variations in the basin by extrapolating data away from boreholes by using a nearest-neighbor 3-D-gridding process. The 3-D-gridding process is a cell-based modeling approach where solid-model cell nodes are sequentially assigned properties radially (horizontally) from each borehole in circles of increasing diameter. The approach is a simple spatial interpolation method that does not consider spatial structure of the data. Cell dimensions for the modeling were $656 \mathrm{ft}(200 \mathrm{~m})$ in the horizontal dimensions and $6.56 \mathrm{ft}(2 \mathrm{~m})$ in the vertical dimension. The cell horizontal dimensions were chosen to mimic the closest spacing of the wells, and the vertical dimension was chosen to preserve the textural detail obtained from analysis of the drillers' logs. The extrapolated lithologies in the resulting solid model have aspect ratios that emphasize the horizontal dimension relative to the vertical dimension, in accordance with the depositional environment.

The upper surface of the 3-D solid lithologic model was clipped at the topographic surface by using a digital elevation model; the base of the model was clipped by using the modeled composite bedrock unit surface. The 3-D modeling approach was ultimately limited by the extrapolation methodology. The method preserved the local variability of the lithology where data were abundant, but likely resulted in poorer extrapolation where drill holes were widely spaced and the outlying points influenced a large part of the model volume.

\section{Collection of Groundwater Level Data}

Water-level data were collected from 59 wells during fall 2013. Most of the 59 wells were part of a monitoring network last measured by the USGS during 2004-07. Wells with historical records were given priority for data collection in 2013 to assess water-level changes through time. Additional areas for water-level collection were identified to fill spatial gaps. Nearly 20 additional wells targeted for inclusion could not be accessed, however, because well-owner permission could not be secured.

Groundwater-level measurements, reported as depth to water (in feet) below land surface, were collected by the USGS by using calibrated steel or electric tapes in accordance with published USGS technical procedures (Cunningham and Schalk, 2011). Water-table altitudes were calculated by subtracting the measured depth to water from the land-surface datum (the altitude of the land surface above North American Vertical Datum 1988; NAVD88). Land-surface altitudes relative the NAVD29 were estimated from topographic maps, then converted to NAVD88. The mean water level and difference from the mean water level for each measurement were computed for each well for the purpose of plotting hydrographs showing water-level change over decades for many different wells on a common scale.

Water-level measurements were collected from October 28 to November 22, 2013. The completed data set for fall
2013 included measurements of water levels in 55 wells; of the wells in which water levels were measured historically, 4 were dry in 2013. All water-level data were quality-checked and entered into the USGS NWIS. These data are available in the appendices and publicly available at http://waterdata.usgs. gov/nwis.

The geologic materials present in the perforated zone of wells, shown in appendix 1, were determined from a previous compilation by Woolfenden and Bright (1988, appendix A) or drillers' logs. For wells in bedrock areas lacking information from these sources, wells were attributed with the bedrock lithology mapped at that location by Dibblee and Minch (2008).

\section{Aquifer Geometry}

The gravity field of the study area (here referred to as the isostatic residual gravity field) reflects the large density contrast between dense basement rocks and lower density alluvial deposits (fig. 5). The most prominent features on the gravity map are the high gravity values (greater than $-14 \mathrm{mGal}$ ) that generally coincided with thin alluvium and basement-complex exposures of granodiorites and metasedimentary rocks along the southern and western boundaries of the groundwater basins and with the low gravity values (less than -14 to $-20 \mathrm{mGal}$ ) that coincided with alluvial deposits, particularly along the San Jacinto fault zone in the northern and northwestern Anza Valley near the Ramona Indian Reservation. The lowest gravity values are parallel to the San Jacinto fault zone beneath the area of Pleistocene alluvium that crops out along the west side of the San Jacinto fault zone and extends northwest, crossing the surface- and groundwater-basin boundaries. This pattern of lower gravity values is typical of faults with substantial displacement. In this case the relative motion on the San Jacinto fault zone has caused the units west of the fault to drop and then fill with alluvium derived from the surrounding highlands.

The alluvial thickness modeled from the gravity data generally agreed with alluvial thickness estimates based on drillers' logs. Discrepancies between the modeled alluvial thickness and estimated values from drillers' logs generally did not follow a coherent spatial pattern; rather, discrepancies appeared to be random, such that logs from closely spaced wells sometimes indicated thicker or shallower alluvium than did the modeled gravity data. The differences between the smoothed modeled alluvial thickness and drillers' logs indicated that much of the variability in the comparisons resulted from uncertainties in alluvial thickness estimated from drillers' logs. The uncertainties in the identification of the alluvium and bedrock surface based on drillers' logs could be due to drilling methods, subtle changes in materials in weathered zones along the alluvium/bedrock interface, or variability in descriptions for holes drilled for the purposes of water supply. 


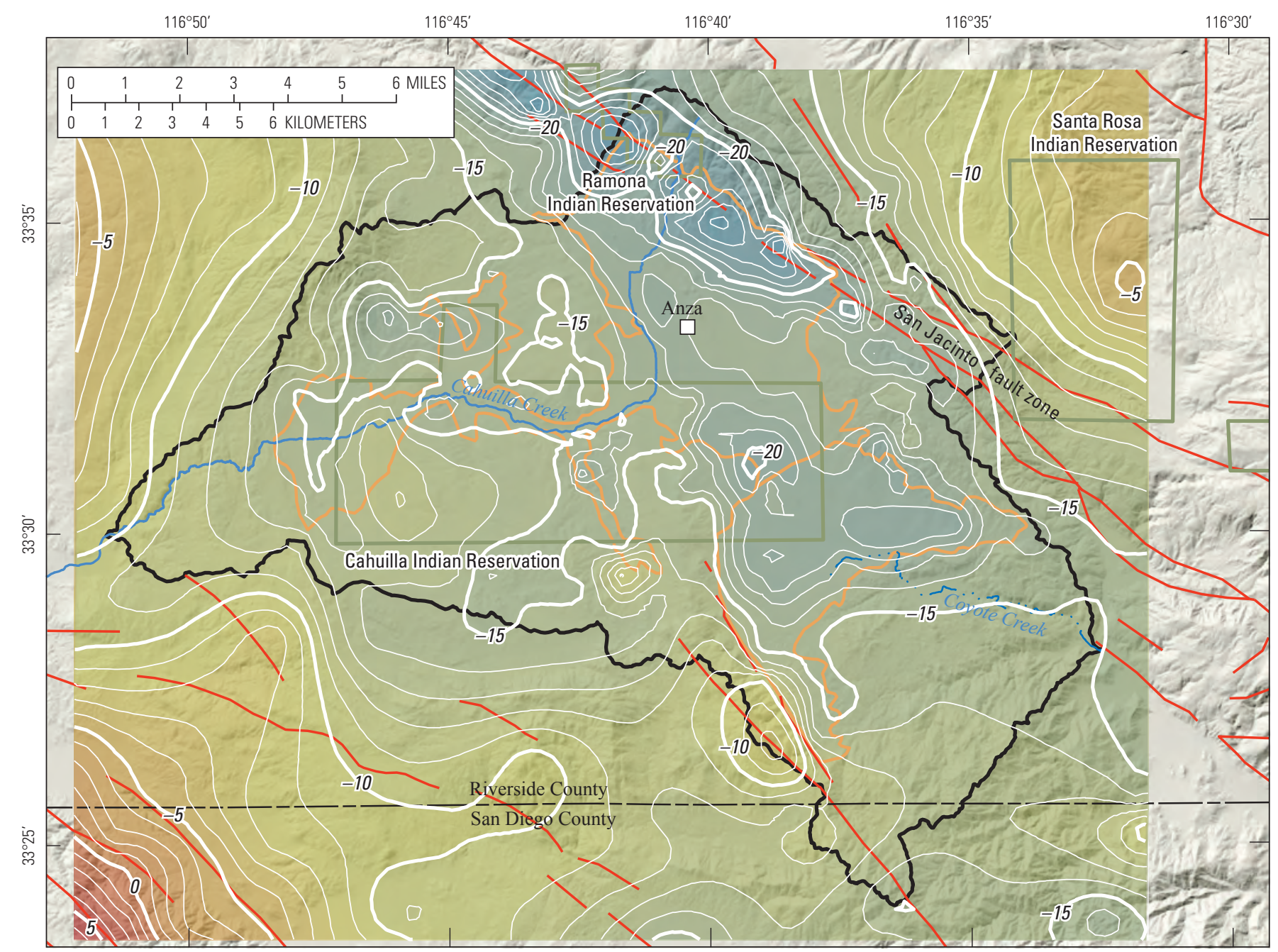

Base from U.S. Geological Survey digital data, 1:100,000, 1981-89; Universal Transverse Mercator Projection, Zone 11.

\section{EXPLANATION}

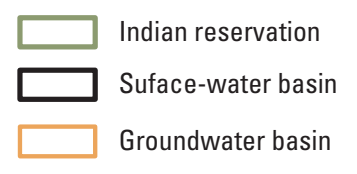

Town

Fault

Gravity contour, interval is 1 milliGal

Figure 5. Isostatic residual gravity field in the Anza-Terwilliger study area, Riverside and San Diego Counties, California.

The thickest alluvium is in the northern part of the study area along the south side of the San Jacinto fault zone (fig. 6). Apparent thickness exceeds $1,000 \mathrm{ft}$ in small areas near the fault. Alluvial thicknesses greater than $500 \mathrm{ft}$ are widespread to the south of the San Jacinto fault zone. It is expected that the area on the south side of the San Jacinto fault zone would have a substantial thickness of alluvium, because the south side of the fault zone has dropped relative to the north side, creating a depression that has been filled in by alluvium.

Additional areas that have alluvial thicknesses greater than $500 \mathrm{ft}$ are in the southern part of the Cahuilla groundwater basin and the western part of the Terwilliger groundwater basin. Through most of the area covered by alluvium, the thickness of the alluvium estimated from gravity data is less than $400 \mathrm{ft}$. There are several areas in the western and eastern Cahuilla groundwater basin and southern Terwilliger groundwater basin where alluvial thicknesses are less than $50 \mathrm{ft}$. The areas of greatest alluvial thickness generally corresponded to apparent gravity anomalies previously identified by Moyle (1976). The thickness model of the alluvium was constructed by combining data from previous gravity studies with new gravity data and applying more advanced models of the data developed since the time of Moyle (1976). 


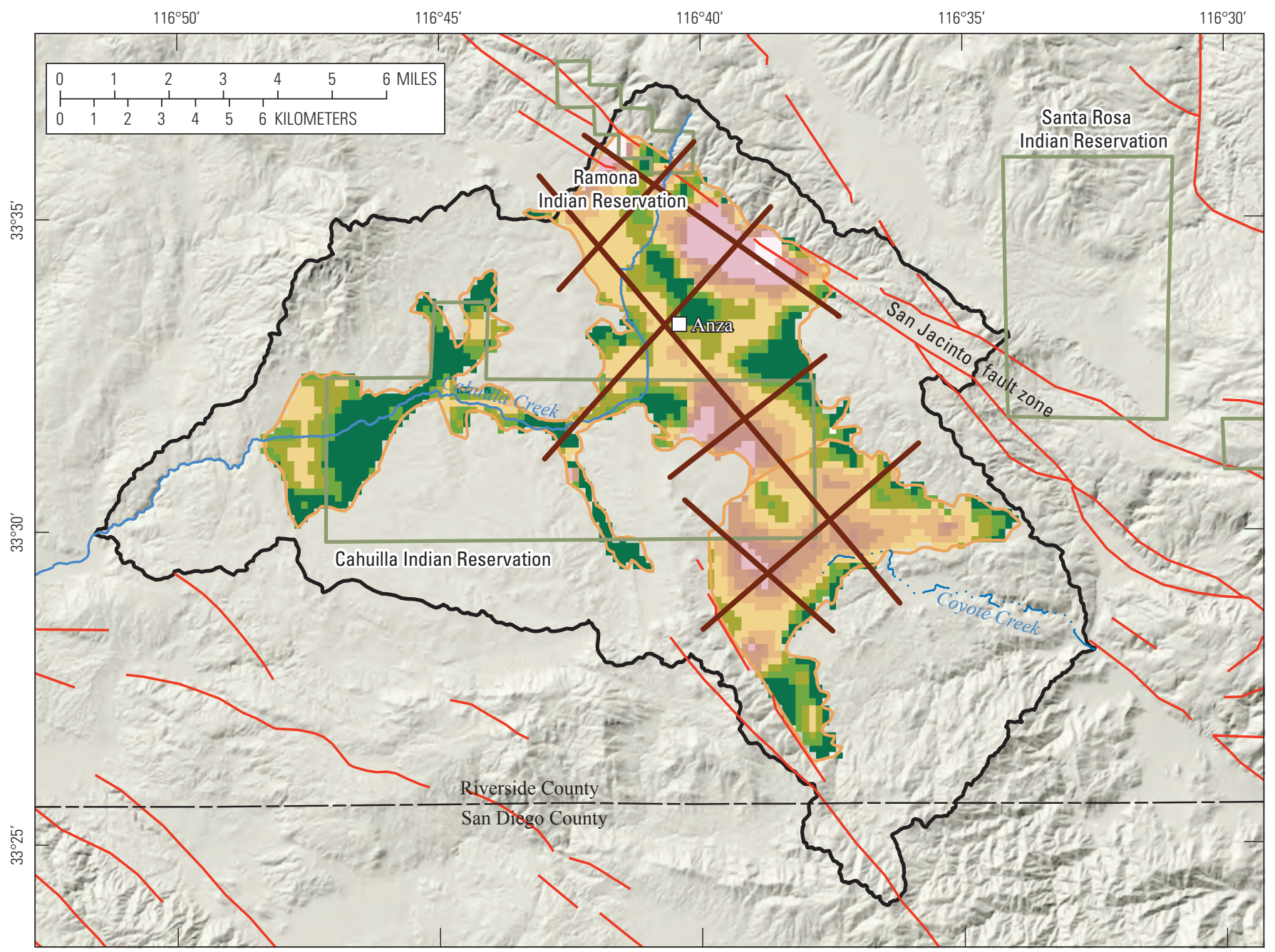

Base from U.S. Geological Survey digital data, 1:100,000, 1981-89;

Universal Transverse Mercator Projection, Zone 11

EXPLANATION

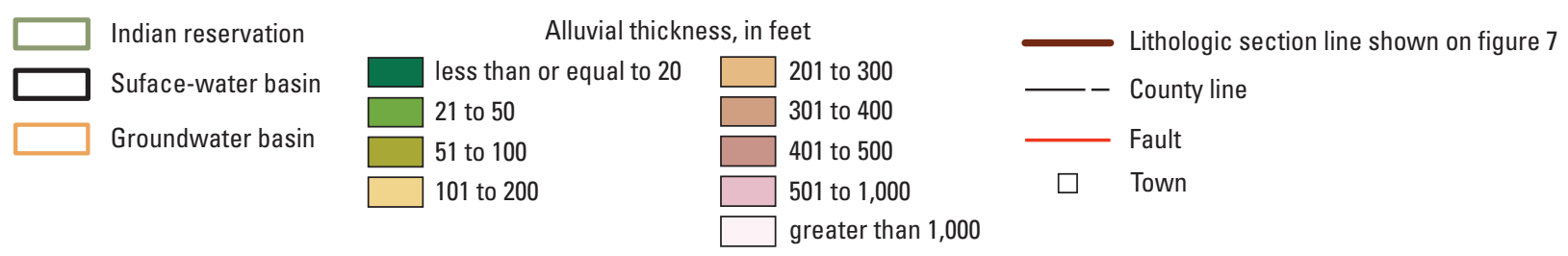

Figure 6. Alluvial thickness based on modeled gravity data and drillers' logs in the Anza-Terwilliger study area, Riverside and San Diego Counties, California.

The alluvial thickness map indicated an area that had an apparent alluvial thickness of 200 to more than $1,000 \mathrm{ft}$ along the northern border of the study area, by the surface-drainage divide and groundwater-basin boundary (fig. 6); groundwater can flow across the basin boundary in this area. Quaternary and Plio-Pleistocene alluvial deposits extend to the northwest beyond the mapped boundary of the Cahuilla groundwater basin (fig. 2). The large thickness was constrained by some drillers' logs near the southern part of this segment of the boundary; there were no drillers' logs along the northern part of this segment (fig. 4). Nevertheless, the geologic maps and relatively low gravity values from previous studies (fig. 5) indicated that a substantial thickness of alluvium continues to the northwest of the mapped boundary of the basin. These alluvial deposits do not connect with any alluvial basins to the northwest, and the connection with fractured bedrock along the San Jacinto fault zone is unknown. Consequently, the magnitude of groundwater flow across this basin boundary is unknown. Historical groundwater-level altitude maps that had sparse nearby data, shown by Woolfenden and Bright (1988), indicated that groundwater flow should be from north to south; if so, cross-boundary groundwater flow is likely to be minor. A future evaluation of groundwater-flow directions and head gradients in this area would determine the influence of groundwater fluxes across this basin boundary on the local groundwater budget. 


\section{Aquifer Geometry, Lithology, and Water Levels in the Anza-Terwilliger Area-2013, Riverside and San Diego Counties}

In spite of improved techniques for estimating alluvial thickness from gravity data, there are important and notable uncertainties in the alluvial thickness map for the study area. Three specific uncertainties are noted in the paragraphs below.

First, the method cannot be used to accurately estimate alluvial thicknesses of less than about $50 \mathrm{ft}$. The gravity anomaly of areas that had alluvium less than 50-ft-thick compared to areas that had no alluvium was not enough to resolve the difference between them. Figure 6 shows areas that have alluvial thickness less than or equal to $20 \mathrm{ft}$ and from 21 to $50 \mathrm{ft}$ to illustrate the basin geometry and show possible areas of very thin alluvium; however, it is appropriate to regard all of these areas as having relatively thin alluvium (less than $50 \mathrm{ft}$ ). As an example, the area of alluvial thickness less than $20 \mathrm{ft}$ immediately north of the town of Anza includes areas of mapped bedrock outcrop (figs. 2, 6); thus, some areas of no alluvial thickness can be included within the area mapped as having alluvial thickness less than $20 \mathrm{ft}$.

Second, the spatial accuracy of the alluvial thickness estimates were subject to the resolution of the values calculated for $656 \mathrm{ft}(200 \mathrm{~m})$ grid cells. The sizes of the grid cells are visible at several locations on the alluvial thickness map (fig. 6). These gridded values show regional-scale spatial patterns in alluvial thickness; local-scale changes in alluvial thickness smaller than the $656 \mathrm{ft}$ grid cells could not be resolved based on the available data.

Third, the uncertainties in alluvial thickness estimates were greatest in areas where drillers' log data were absent, such as in the Cahuilla Reservation. In the absence of drillers' log data to constrain the thickness of alluvium at known points (fig. 4), the bedrock surface was modeled from gravity and bedrock outcrop data alone, leading to more poorly constrained estimates. An important illustration of uncertainties was within the reservation in the southern Cahuilla groundwater basin, where a relatively deep hole of alluvial thickness more than $400 \mathrm{ft}$ was apparent on the alluvial thickness map (fig. 6). In this area, the largest thickness of greater than $500 \mathrm{ft}$ is near the edge of the alluvium. Such a pattern could result if a subsurface feature, such as a fault, resulted in a large and sharp contrast in alluvial thickness. For example, such a large contrast in thickness is along the mapped San Jacinto fault zone in the northern part of the study area. Given the lack of data in the southern Anza Valley within the reservation, it is possible that a previously unmapped fault along the alluvial margin is present in this area. Alternatively, it is also possible that the area of substantial alluvial thickness is an artifact of an unusual density contrast between the underlying bedrock and the alluvium in the area that differs from that assumed in the inversion. If the contrast between the density of the underlying bedrock and the alluvium were larger than in surrounding areas, the alluvial thickness in that area would not be as large as indicated. A larger density contrast could result from higher density bedrock or lower density alluvium (finer grained). Determining the explanation for this large apparent thickness near the edge of the alluvium would require additional subsurface data in this area, so these estimates should be regarded as preliminary.

\section{Aquifer Lithology}

Analysis of drillers' logs indicated that the basement rocks are an important water source for domestic use in the study area. On the basis of the available logs, many more wells have been drilled into bedrock than alluvium in the study area. Of 931 drillers' logs compiled in the study area, 582 indicated only bedrock was encountered in the subsurface; 238 penetrated the full thickness of the alluvium and then continued into bedrock; and 111 described only alluvium, indicating that the drilling was terminated before bedrock was encountered (fig. 4). The bedrock-only wells were particularly dense at the western downgradient edge of the Cahuilla groundwater basin, in the north-central part of the study area, and to the east of the Anza Valley; each of these areas predominantly consists of Cretaceous quartz diorite to granodiorite (fig. 2). In addition, there were abundant bedrockonly wells in the northwestern part of the study area and the north-central part of the Anza Valley in an area of bedrock outcrop surrounded by alluvium, in which the predominant rock type is Paleozoic to Mesozoic metasedimentary rocks.

The proximity and co-location of wells with only alluvium, only bedrock, or both in areas, such as the northern Anza Valley, indicated that the basement rocks and alluvium both are important sources of water supply in some areas and could serve as a connected aquifer system (see additional discussion in the "Water-Level Change" section). Many wells drilled through alluvium into bedrock were in close proximity to areas with many bedrock-only wells near the western and eastern margins of the alluvial basins and in the northern Anza Valley (fig. 4). Many of these wells indicated well perforations that both spanned alluvial deposits and underlying fractured bedrock. 
The depths of penetration into the bedrock of many wells, up to several hundred feet, indicated that fractures potentially supplying water to wells persist to a considerable depth and that the permeable zone of the fractured bedrock extends through the weathered part of the bedrock into competent rock. Weathered zones in bedrock can be highly permeable; however, the drillers' logs in the study area did not generally describe extensive weathered zones near the bedrock surface.

The wells that terminated in alluvium were generally in the western Cahuilla groundwater basin, in the northeastern and south central Anza Valleys, and in central Terwilliger Valley. In these areas, the alluvium is relatively thick.

Determinations of the relative importance of bedrock and alluvium as aquifers in the study area were affected by the uneven distribution of data and the sometimes limited quality of information available from drillers' logs. For example, there were few drillers' logs available for wells within the Cahuilla Reservation; the available logs indicated areas of substantial alluvial thickness within the reservation only in the southern Anza Valley and central Terwilliger basin. The Cahuilla Reservation is otherwise generally dominated by granodioritic bedrock and thin alluvium along Cahuilla Creek (fig. 2). However, there are great unknowns in this large part of the study area owing to the scarcity of available wells. In addition, some drillers' logs coded as only bedrock were from areas mapped as having at least thin alluvium present (see figs. 2, 4); an example is the eastern part of the Anza alluvial valley. In places where the alluvium is thin, the presence of alluvial materials was not always clearly identified in drillers' logs, which was a limitation of this data source.

The alluvium is predominantly composed of sand and gravel with interbedded, generally discontinuous, finer textured silts and clays. A series of vertical northwestsoutheast and northeast-southwest sections through the 3-D solid lithologic model portray the lithologic variability of the alluvium in the Anza Valley region as extrapolated from the borehole data (fig. 7). Figure 7 shows a 3-D visualization of seven classified lithologic groups and the bedrock based on the database of drillers' logs descriptions from the study; the figure shows an oblique view of the lithologies present in boreholes and along selected cross-sections through the alluvial sediments. The cross-sections, selected at approximately right angles, form a fence diagram illustrating the distribution of lithologies in 3-D. Note that alluvium also is between the cross-sections shown, but is not shown on the figure so the selected cross-sections are viewable. Lithologies between sections are represented in cylindrical boreholes. The bedrock surface is at land surface outside alluvial groundwater basins and underneath the alluvium in basins (shaded gray in figure $7 A$ and is uncolored in figure $7 B$ ).
The lithologic visualization shows the many wells that have been drilled into bedrock outside and underneath the alluvial basins (fig. 7). In particular, many logs in the northern part of the Anza Valley are from wells drilled through relatively thin alluvium into bedrock.

In areas having relatively large thickness of alluvial sediments, particularly along the San Jacinto fault zone and in the Terwilliger Valley, the alluvium is predominantly composed of sands and gravels (fig. 7). In the area south of the San Jacinto fault zone, fine-textured sediments primarily are in the middle to deeper parts of the alluvial sediments. Fine-textured sediments appeared to be discontinuous, rather than forming laterally extensive low-permeability zones, with the apparent exception of the southern Anza Valley, which is discussed later in this section. The extent to which these discontinuous clayey zones could serve as confining units is unknown because of the lack of water-level data from short-screened wells perforated above and below those finetextured zones. In parts of the southeastern and northwestern deep alluvial sediments near the San Jacinto fault zone, coarse-textured sediments are present throughout most of the thickness of the alluvial sediments. In the area of relatively thick alluvium in the Terwilliger Valley, the alluvium is predominantly composed of sand; where the alluvium thins, interbedded clays and sand are predominant.

Although data were sparse, sediments in the thinner alluvial deposits between the boundaries of the Cahuilla and Terwilliger groundwater basins appeared to be relatively fine textured. The thin and fine-textured deposits have the potential to limit groundwater fluxes across the boundary between the Terwilliger and Cahuilla groundwater basins.

In the area of thick alluvial deposits in the southern Anza Valley, the very sparse log data indicated that the sediments are well stratified, with upper, middle, and basal sands and gravels separated by clays. The inferred persistence of these layers over large horizontal distances reflected extrapolation between widely spaced drillers' logs in this area. The deposits could be substantially more heterogeneous in this area than are indicated, as is the case in other areas of the basin where denser log data were available.

As noted earlier in the discussion of use of drillers' log data to map depth to bedrock, substantial variability in the lithologic descriptions in drillers' logs led to uncertainties in regional lithologic distributions. Visualization of spatial patterns based on the ensemble of lithologic data from hundreds of logs allowed for the identification of general patterns at a regional scale, however. 

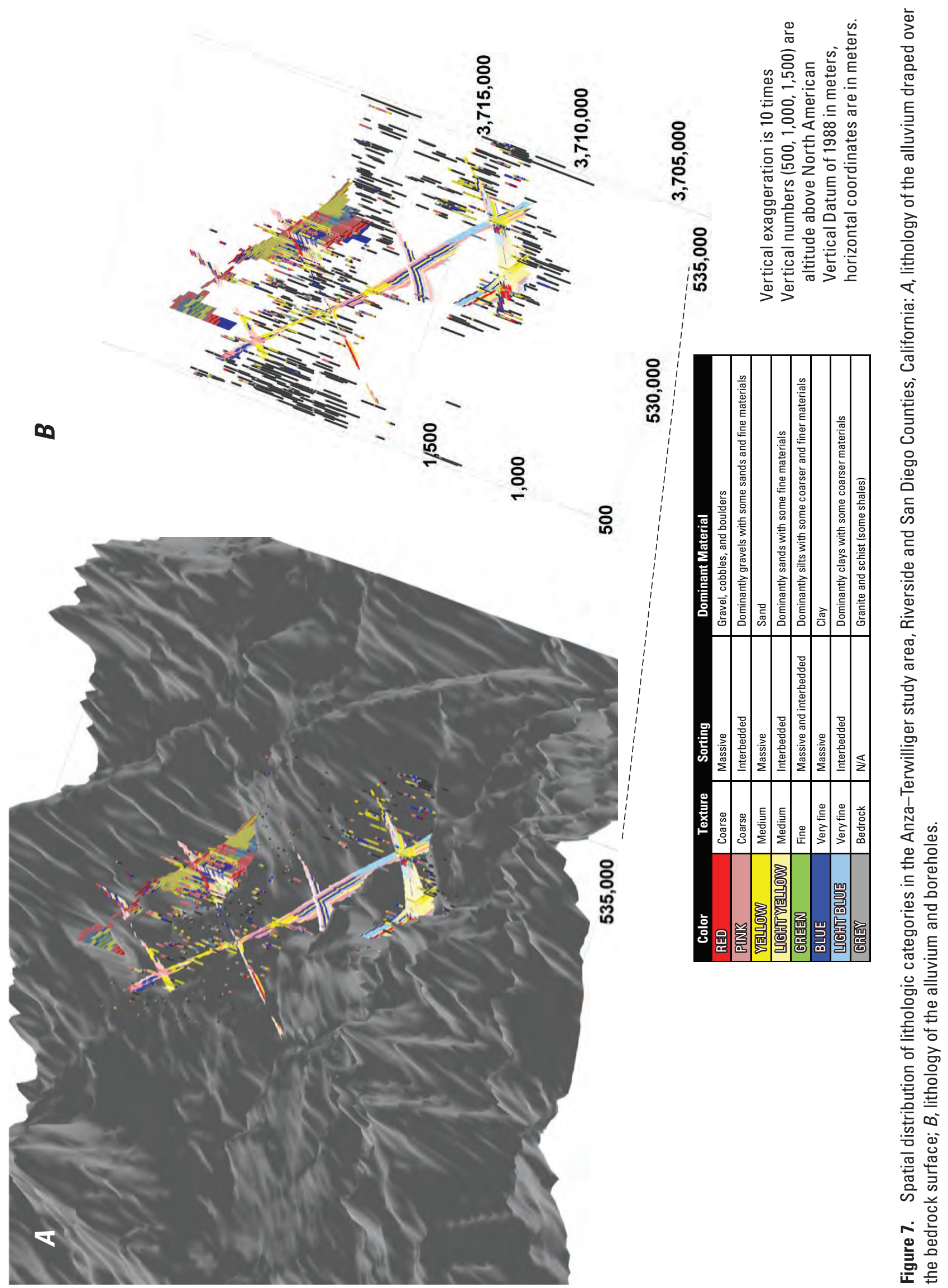


\section{Groundwater Levels}

In general, groundwater flows from areas of higher to areas of lower hydraulic head (head is equivalent to waterlevel altitude in a well) and perpendicular to lines of equal hydraulic head. Prior to 1950, when the effects of pumping on the water table in the study area were probably minimal, movement of groundwater was toward major streams in the Anza and Terwilliger Valleys (Moyle, 1976). The water-table surface sloped from its highest altitudes in the consolidated rocks in the mountains toward Cahuilla and Coyote Creeks. Averaged over long periods, groundwater discharge equaled recharge, and the system was in a steady-state condition (Woolfenden and Bright, 1988). Since that time, USGS studies by Moyle (1976) and Woolfenden and Bright (1988) have identified areas in the alluvium where groundwater moved toward water-table depressions in the central and northeast Anza valley where groundwater pumping, primarily for irrigation, has been prevalent.

\section{Water-Level Altitude}

Groundwater altitudes ranged from 4,332 ft (7S/3E-10B1) to 3,370 ft (7S/3E-32D3) across the study area in fall 2013 (fig. 8; appendix 3). The water-level altitudes were calculated from measurements in wells perforated at differing depths in the groundwater system. These limited data indicated that hydraulic head did not vary substantially with depth and that the measured water levels in consolidated rocks and alluvium were similar (Woolfenden and Bright, 1988). Given the limited spatial distribution of water-level data collected during fall 2013, contouring of the data was not appropriate.

Large differences in groundwater altitude across the San Jacinto fault zone indicated that the fault is a barrier to groundwater flow in the northeastern part of the Anza Valley. Water-level altitudes on the east side of the fault were hundreds of feet higher than on the west. For example, at a distance of less than 1 mile, nearly 435 vertical $\mathrm{ft}$ separated the water-level altitudes in wells $7 \mathrm{~S} / 3 \mathrm{E}-11 \mathrm{P} 3(3,770.6 \mathrm{ft})$, west of the fault, and 7S/3E-13D1 (4,205.1 ft), east of the fault (fig. 8). Several other wells in the immediate vicinity showed similar offsets (wells west of the fault, 7S/3E-11N5, 3,764.9 ft and 7S/3E-14D1, 3,755.3 ft; wells east of the fault, $7 \mathrm{~S} / 3 \mathrm{E}-10 \mathrm{~B} 1,4,331.7 \mathrm{ft}$ and $7 \mathrm{~S} / 3 \mathrm{E}-13 \mathrm{C} 1,4,187.5 \mathrm{ft})$. The barrier effect of the fault is likely caused by compaction and deformation of water-bearing deposits immediately next to the fault and by cementation of the fault zone by mineral deposits from groundwater (Londquist and Martin, 1991). Fault gouge, which is fine-textured sediment or rock that fills fault planes, has been documented in the San Jacinto fault zone (Dor and others, 2006).

\section{Water-Level Change}

Water-level changes were determined by comparing fall 2013 groundwater levels with previous water-level measurements collected in fall 2004 and fall 2006. Because water levels in the study area varied seasonally, change estimates were only based on the comparison of measurements taken in fall of different years. Some water-level measurements were also taken during spring 2004-07, but were not used in this analysis because no spring data for later years were available. Fall measurements typically represent a period of relatively stable water levels that record groundwater altitudes after recovery from the summer irrigation season, but before substantial groundwater recharge from winter precipitation and snowmelt. Historical data for wells measured in fall 2013 are provided in appendix 2. The spatial distribution of water-level change between the fall of 2006 and 2013 and between the fall of 2004 and 2013 is shown in figures 9 and 10, respectively. The water-level change figures use a graduated scale, where symbol size is proportionate to the calculated water-level change. Changes in water levels between measurement periods are listed in appendix 4 .

Water-level measurements in 33 wells showed that changes in water-table altitude between the fall of 2006 and the fall of 2013 ranged from a decline of $31.0 \mathrm{ft}$ (well 7S/3E-11P3) to a rise of $36.2 \mathrm{ft}$ (well 7S/3E-24C2; fig. 9). The median change was a decline of $5.1 \mathrm{ft}$ between fall 2006 and fall 2013, and the median rate of decline was 0.73 feet per year (ft/yr). Of the 33 wells, 2 wells had increases in groundwater altitude between fall 2006 and fall 2013 (7S/3E-24C2, 36.2 ft; 7S/2E-32D3, $15.9 \mathrm{ft}$ ); the remaining 31 wells had decreases in groundwater altitude ranging from $0.9 \mathrm{ft}(7 \mathrm{~S} / 3 \mathrm{E}-17 \mathrm{H} 3)$ to $31.0 \mathrm{ft}(7 \mathrm{~S} / 3 \mathrm{E}-11 \mathrm{P} 3)$.

Water-level measurements in 40 wells showed that changes in water-table altitude between the fall of 2004 and the fall of 2013 ranged from a decline of $28.2 \mathrm{ft}$ (well 7S/3E-11P3) to a rise of $46.9 \mathrm{ft}$ (well 7S/3E-24C2; fig. 10). The median change was a decline of $2.4 \mathrm{ft}$ between fall 2004 and fall 2013, and the median rate of decline was $0.27 \mathrm{ft} / \mathrm{yr}$. Of the 40 wells, 12 had increases in groundwater altitude, and 28 had declines.

The apparent rate of groundwater-level decline from 2004 to 2013 was less than from 2006 to 2013 (figs. 9, 10; appendix 4). The difference in the magnitude of groundwater declines between these two periods reflected conditions that were wetter preceding the fall 2006 measurements than the fall 2004 measurements. These fluctuations in rates of groundwater-level change highlight the value of ongoing water-level measurements to distinguish long-term (decadal or longer) trends from fluctuations associated with short-term climatic variability. 


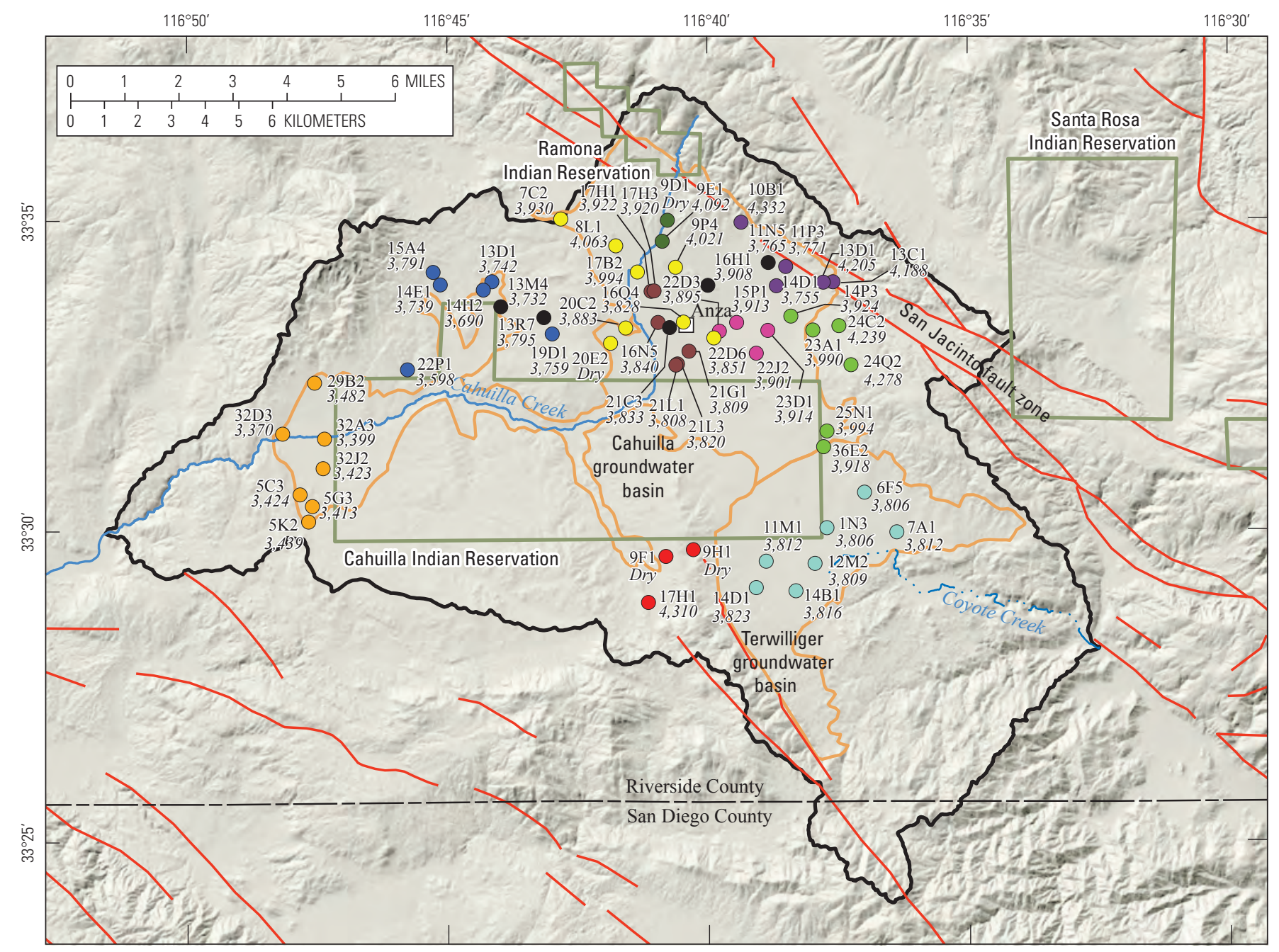

Base from U.S. Geological Survey digital data, 1:100,000, 1981-89; Universal Transverse Mercator Projection, Zone 11.

\section{EXPLANATION}
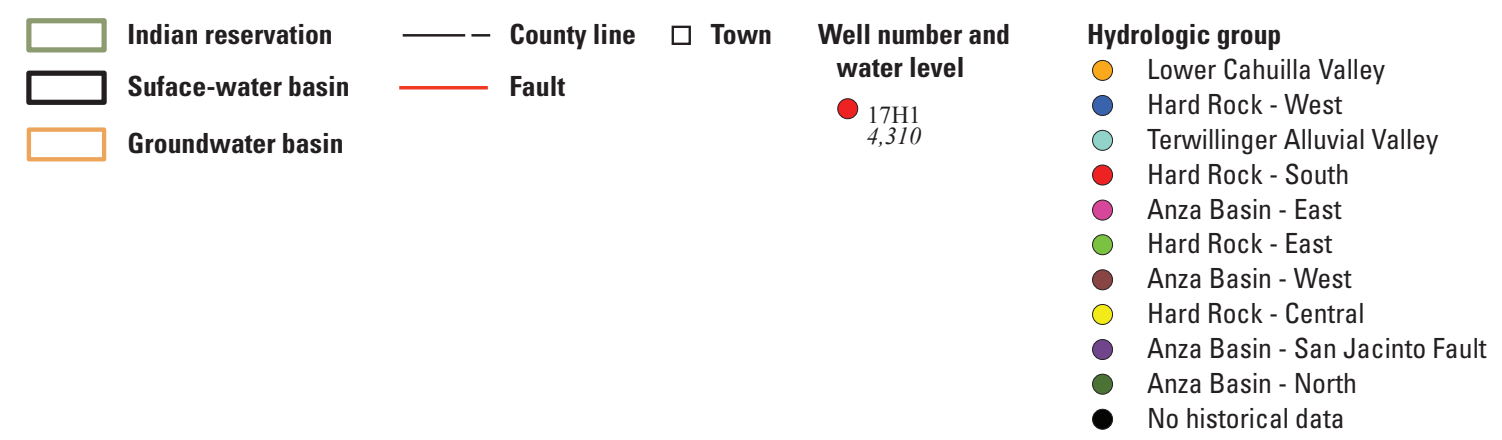

Figure 8. Groundwater-level altitude for October-December 2013, Riverside and San Diego Counties, California. Symbol colors correspond to geographic or aquifer categories by which hydrographs are grouped in figure 11.

The greatest decrease in water level was found in the northeast part of the Anza Valley, next to the San Jacinto fault zone. In this area, well 7S/3E-11P3 has displayed substantial decreases in water level during its recorded history; as of 2013, the water level had dropped $31 \mathrm{ft}$ since 2006 and $76 \mathrm{ft}$ since 1986 (appendix 3).
Fifty-four hydrographs showed long-term and shortterm water-level changes spanning the study area (fig. 11). Heavy seasonal precipitation beginning in the winter of 2005 was evident by relative increases in groundwater altitude between 2004 and 2006. Many of the long-term hydrographs, however, indicated a general decline in water levels across the study area since 1986 and, in some cases, dating back to 


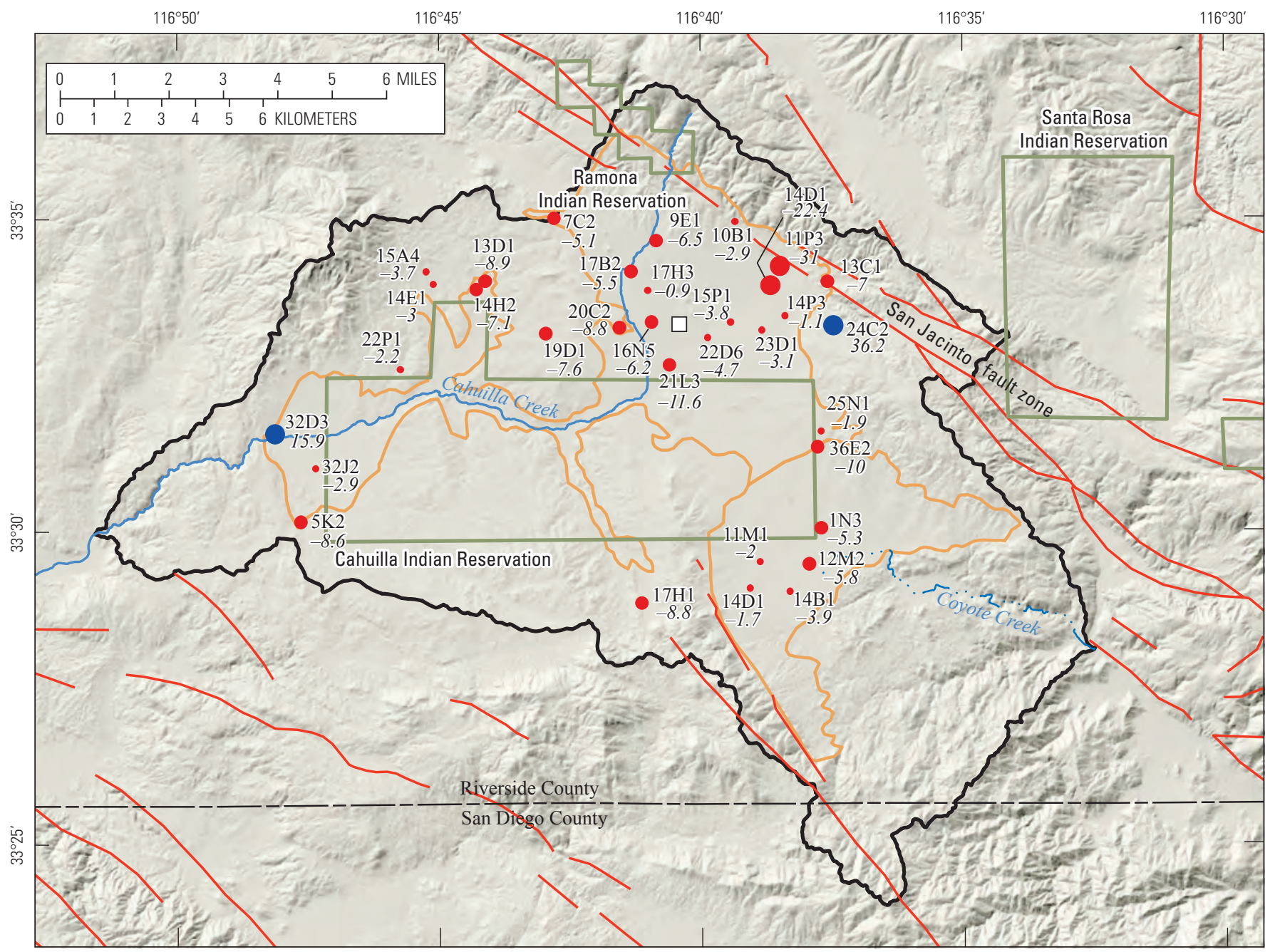

Base from U.S. Geological Survey digital data, 1:100,000, 1981-89; Universal Transverse Mercator Projection, Zone 11.

\section{EXPLANATION}
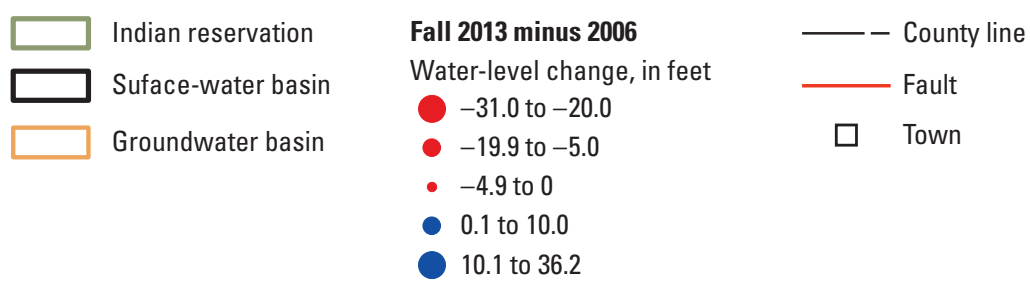

Figure 9. Change in groundwater altitude from fall 2006 to fall 2013, Riverside and San Diego Counties, California.

the onset of data collection in the 1950s. The hydrographs show wells grouped both spatially and according to the hydrologic unit from which water is extracted. This allowed for a direct comparison of relative changes in water level, not only between wells spatially, but also between geologic units (fig. 11). In the cases of Anza and Terwilliger Valleys, little variation was observed between alluvial and fractured granitic and metasedimentary rocks (with the exception of fault-bounded areas), indicating that the units are hydraulically well connected.

The change in water storage in the groundwater system was not calculated because it was beyond the scope of the study. Analysis of a change in storage would need to include analysis of the groundwater storage characteristics of the alluvium and bedrock in combination with the 3-D distribution of lithology. 


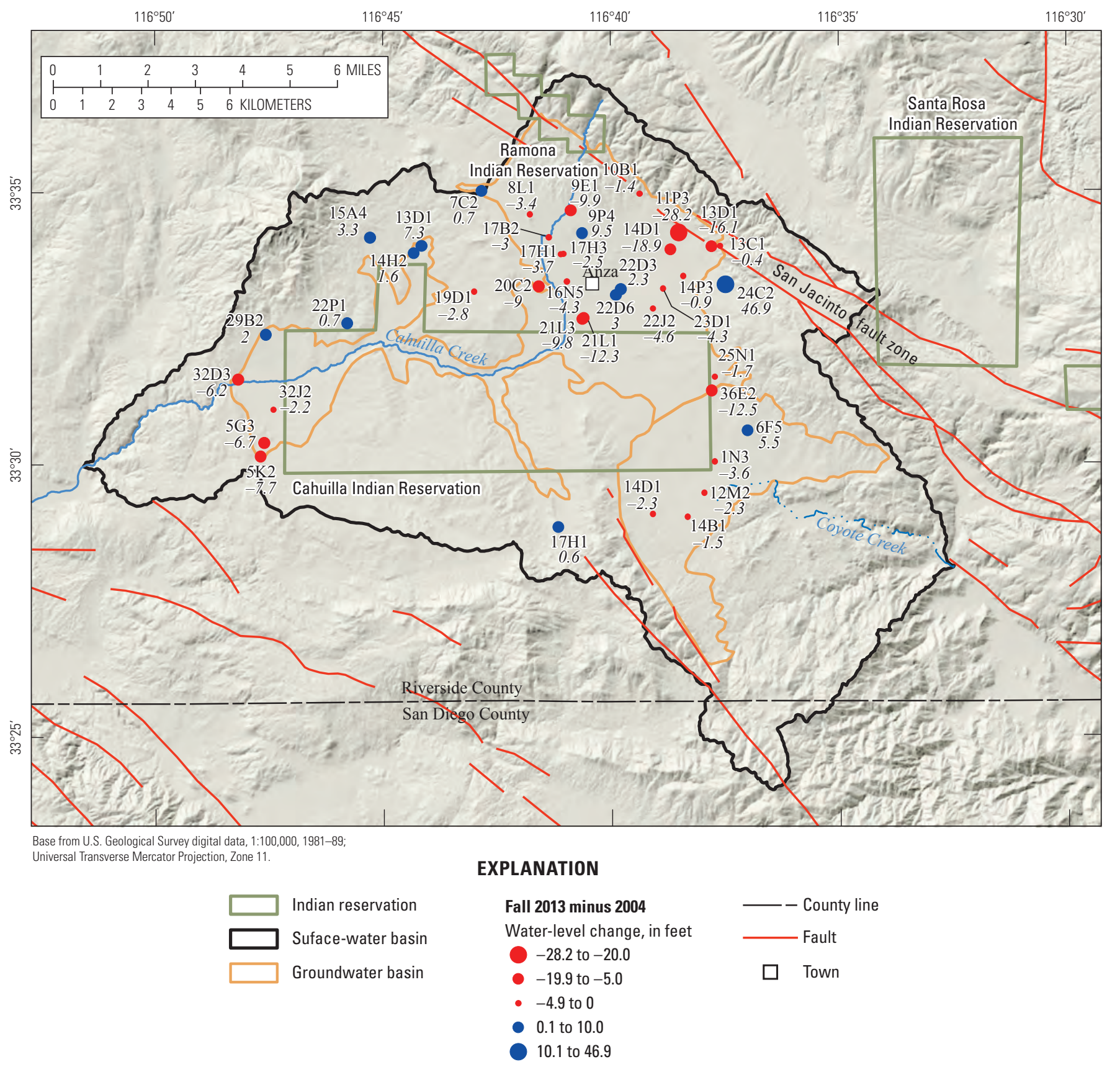

Figure 10. Change in groundwater altitude from fall 2004 to fall 2013, Riverside and San Diego Counties, California. 
Lower Cahuilla Valley

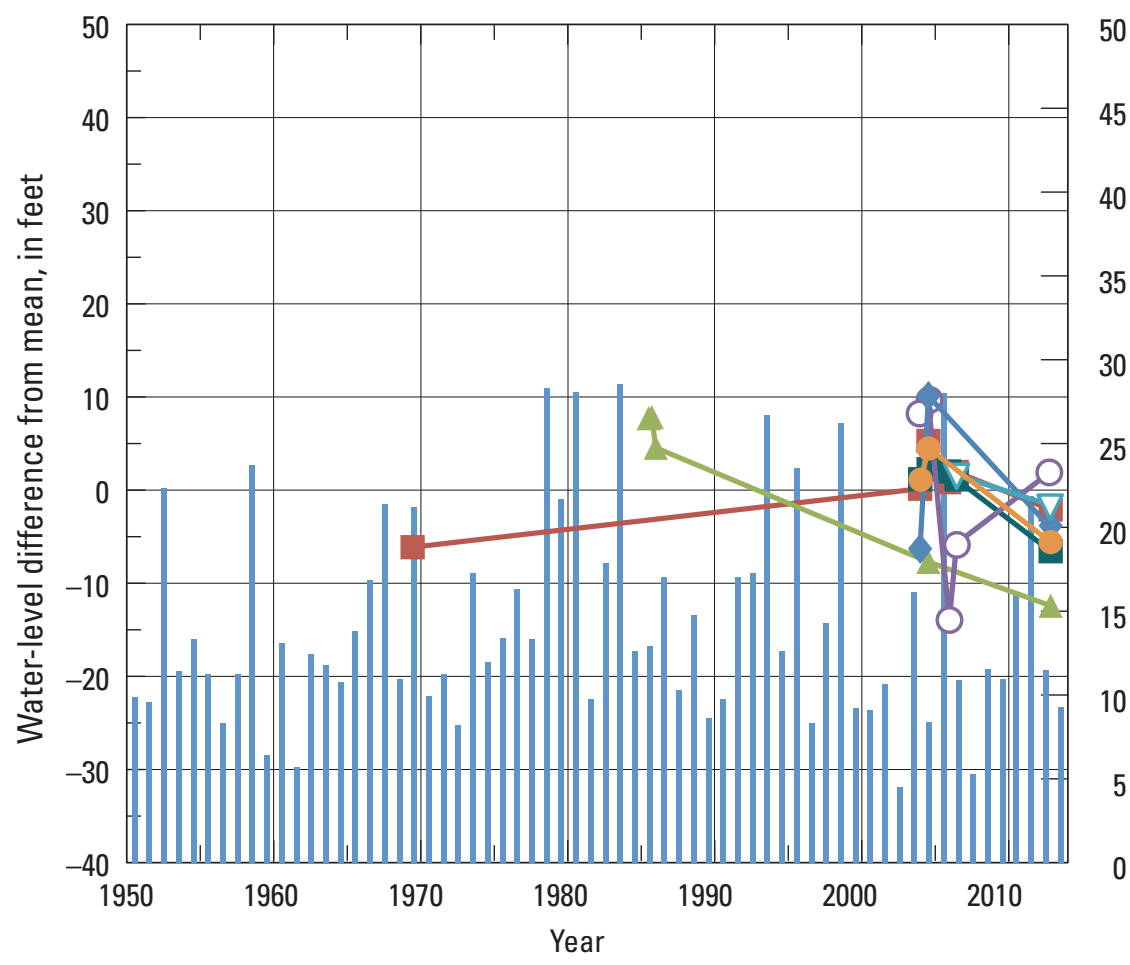

Hard Rock-West

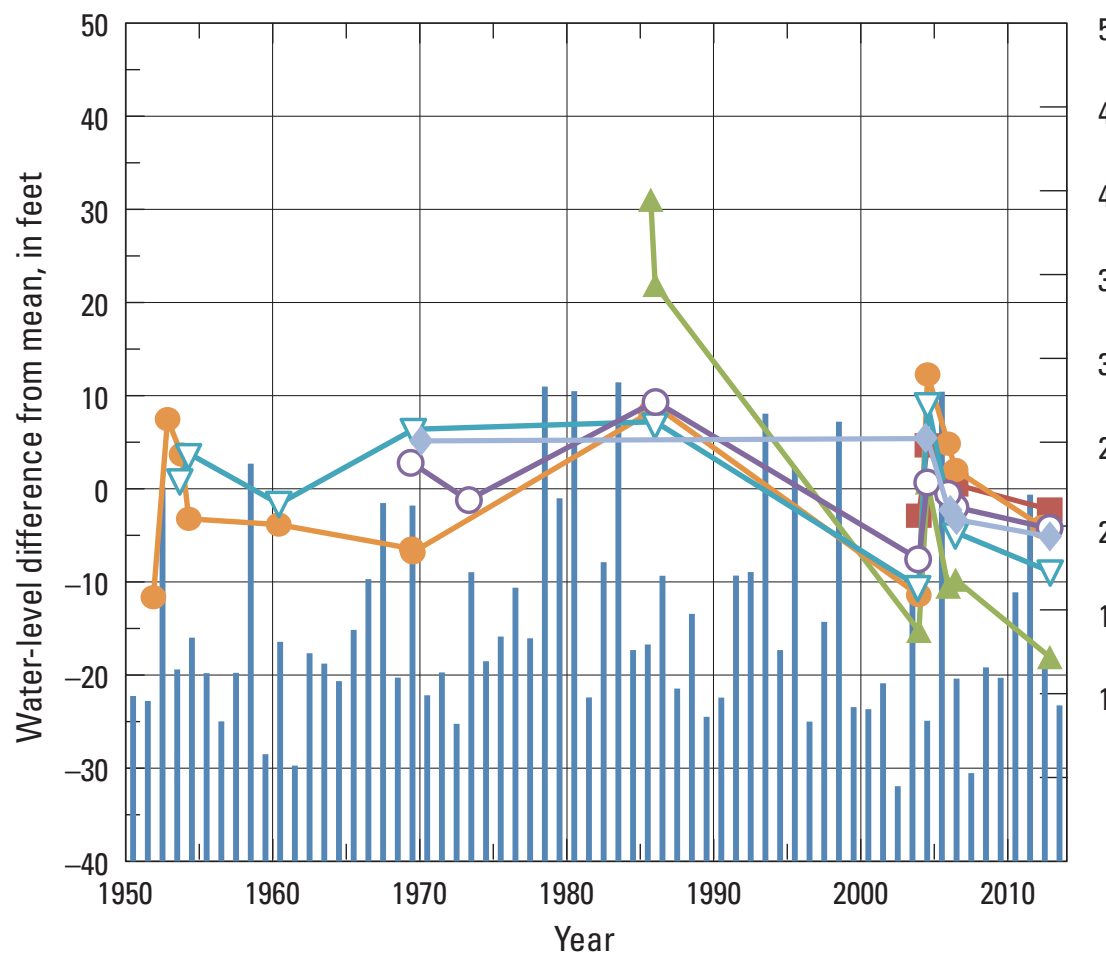

45

40

35

30

25

15

10

5

0

50

45

40

35

30

25

20

20

15

10

5

0
EXPLANATION

Well and State well number

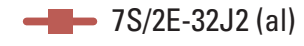

$\longrightarrow$ 7S/2E-32A3 (al)

- 7S/2E-32D3 (al)

7S/2E-29B2 (WZ/BD)

-8 - 8S/2E-5C3 (WZ/BR)

$8 \mathrm{~S} / 2 \mathrm{E}-5 \mathrm{G} 3$ (BR)

$8 \mathrm{~S} / 2 \mathrm{E}-5 \mathrm{~K} 2$ (BR)

Precipitation
7S/2E-22P1 (BR)

- 7S/3E-19D1 (WZ/BR)

$-\nabla-7 \mathrm{~S} / 2 \mathrm{E}-14 \mathrm{H} 2$ (BR)

- -7S/2E-13D1 (WZ/BR)

$\neg-7 S / 2 E-14 E 1$ (WZ/BR)

$-\mathrm{O}-7 \mathrm{~S} / 2 \mathrm{E}-15 \mathrm{~A} 4$ (WZ/BR)

Precipitation

Figure 11. Relative changes in groundwater levels, 1950-2013, Riverside and San Diego Counties, California. Multiple wells are shown on each hydrograph; the wells are organized into hydrologic groups for illustration. Figure 8 shows the location of wells in each hydrologic group, which were named according to geographic area and groundwater aquifer rock type. Abbreviations for geologic material surrounding well perforations or open intervals: al, alluvium; BR, bedrock; Oal, older alluvium; WZ, weathered zone of bedrock; unk, unknown (geologic material descriptions from Woolfenden and Bright, 1988). Annual precipitation data from Flint and others (2013). 
Anza Basin-East

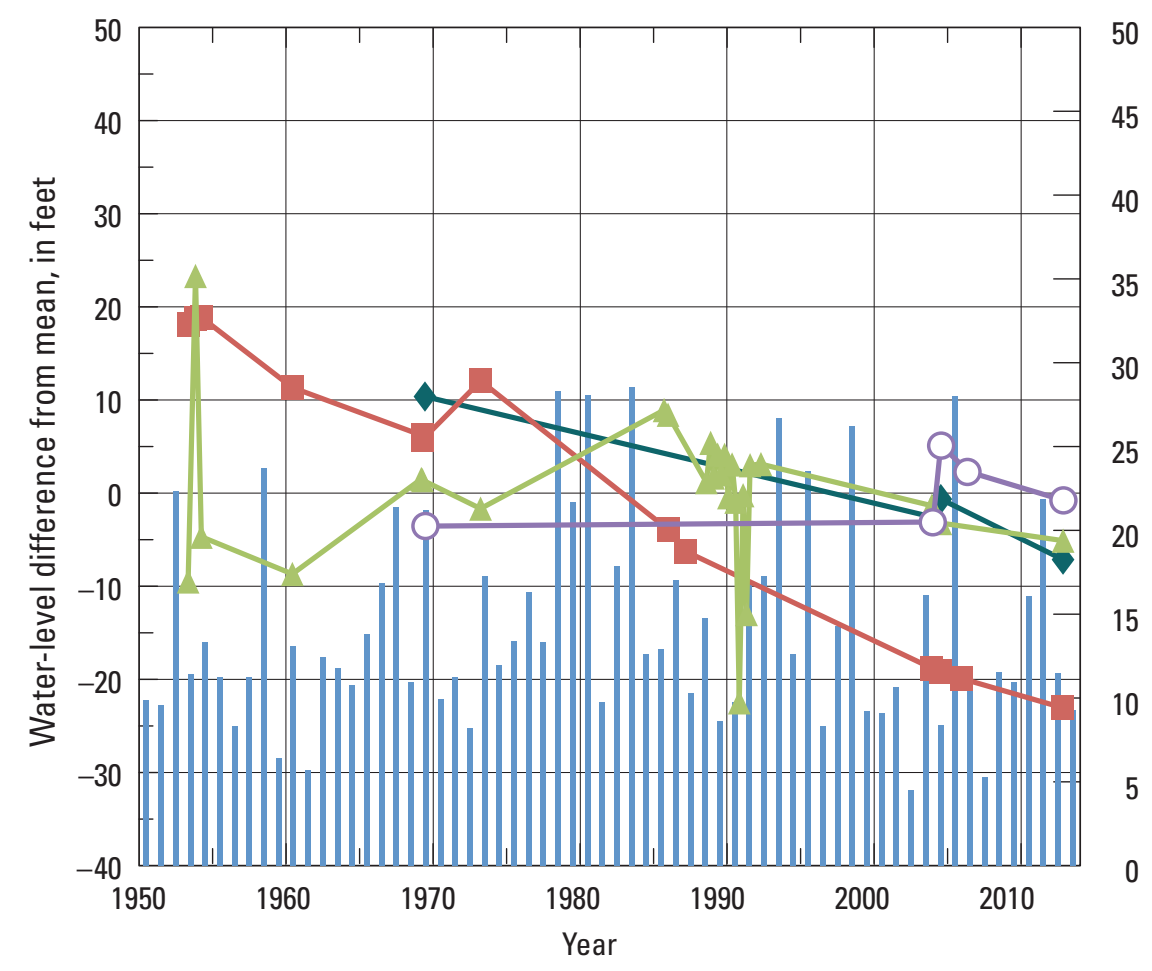

Hard Rock-East

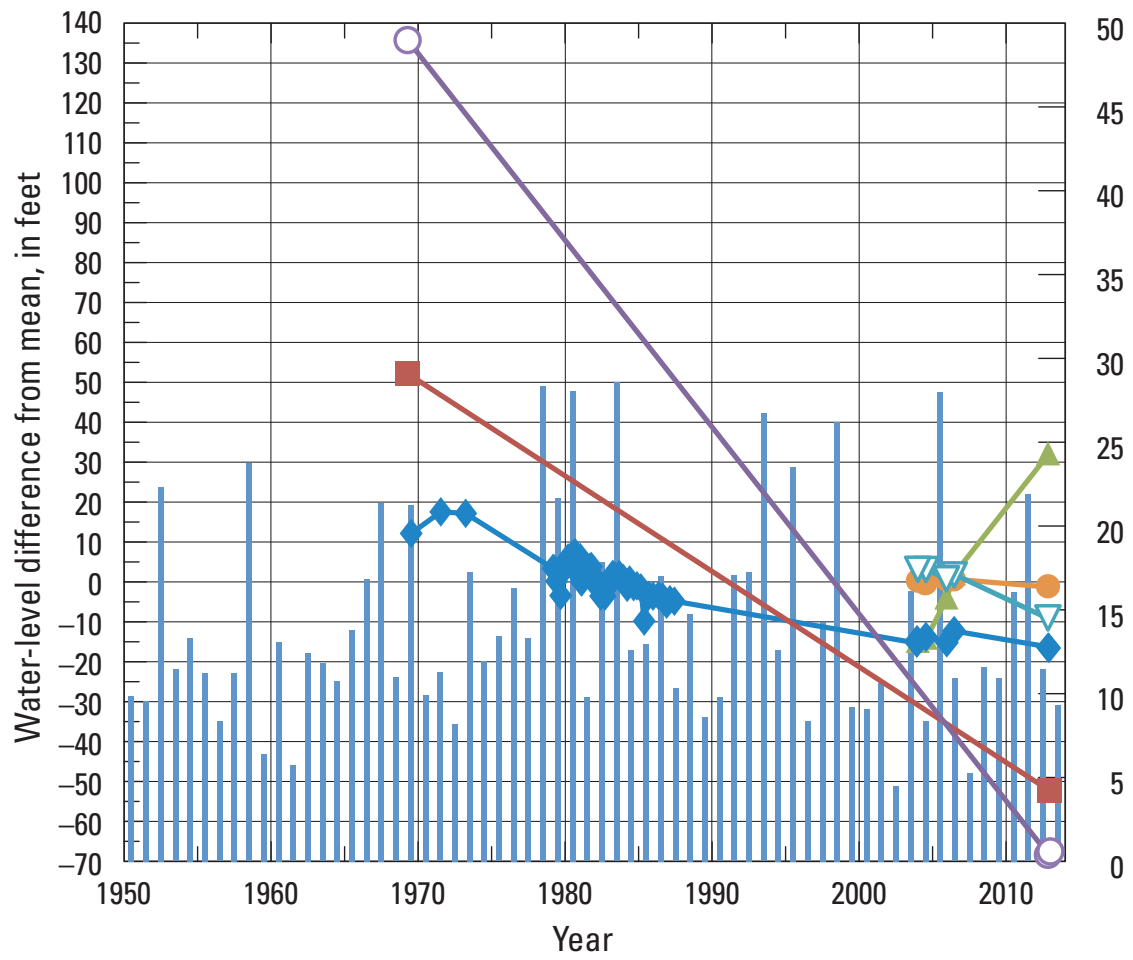

\section{EXPLANATION}

Well and State well number

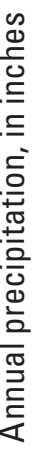

$-7 \mathrm{~S} / 3 \mathrm{E}-22 \mathrm{~J} 2$ (al)

- 7S/3E-23D1 (al)

$-7 \mathrm{~S} / 3 \mathrm{E}-15 \mathrm{P} 1$ (unk)

$-\mathrm{O}-7 \mathrm{~S} / 3 \mathrm{E}-22 \mathrm{D} 3$ (unk)

Precipitation

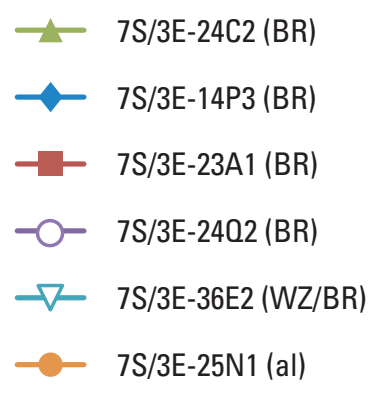

Precipitation

Figure 11. - Continued 
Anza Basin-San Jacinto Fault

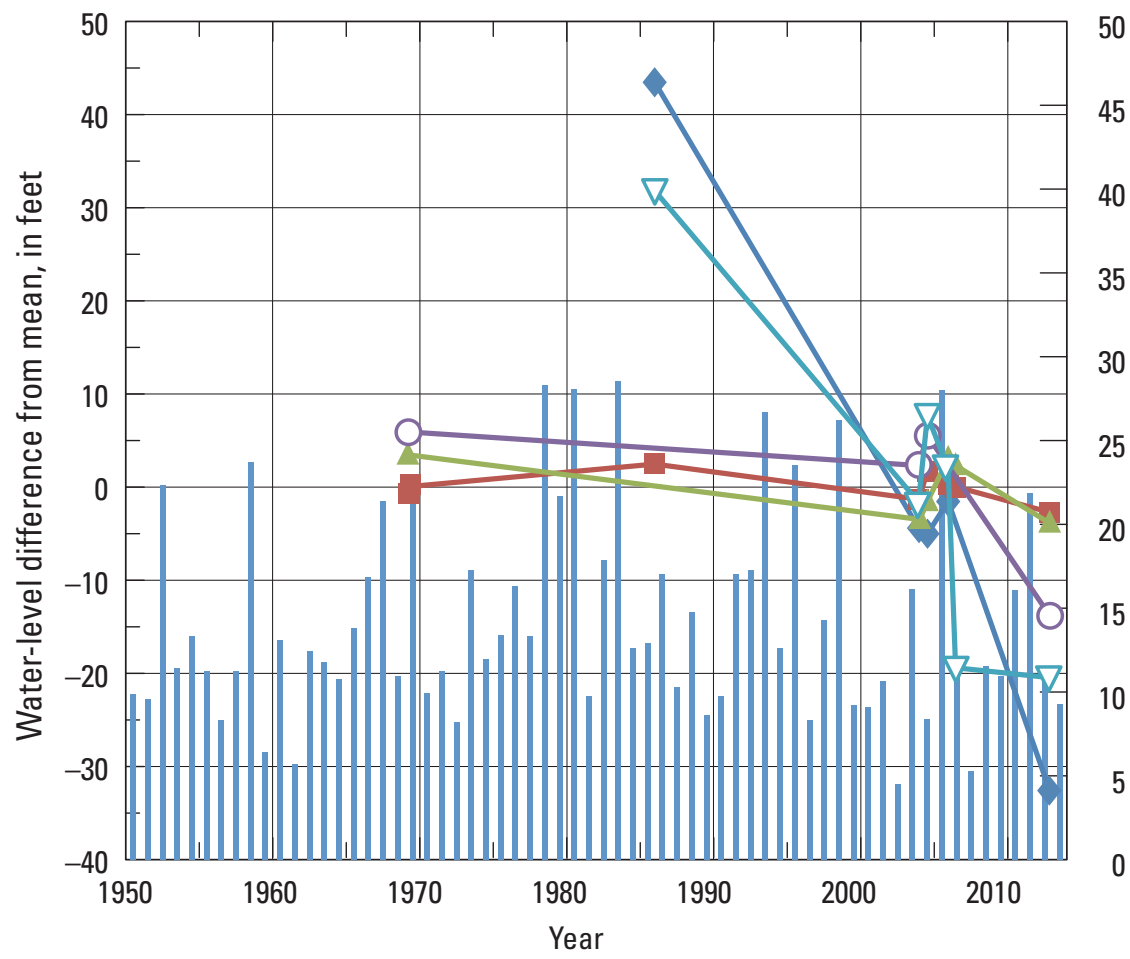

50

45

40

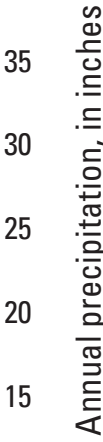

Anza Basin-North

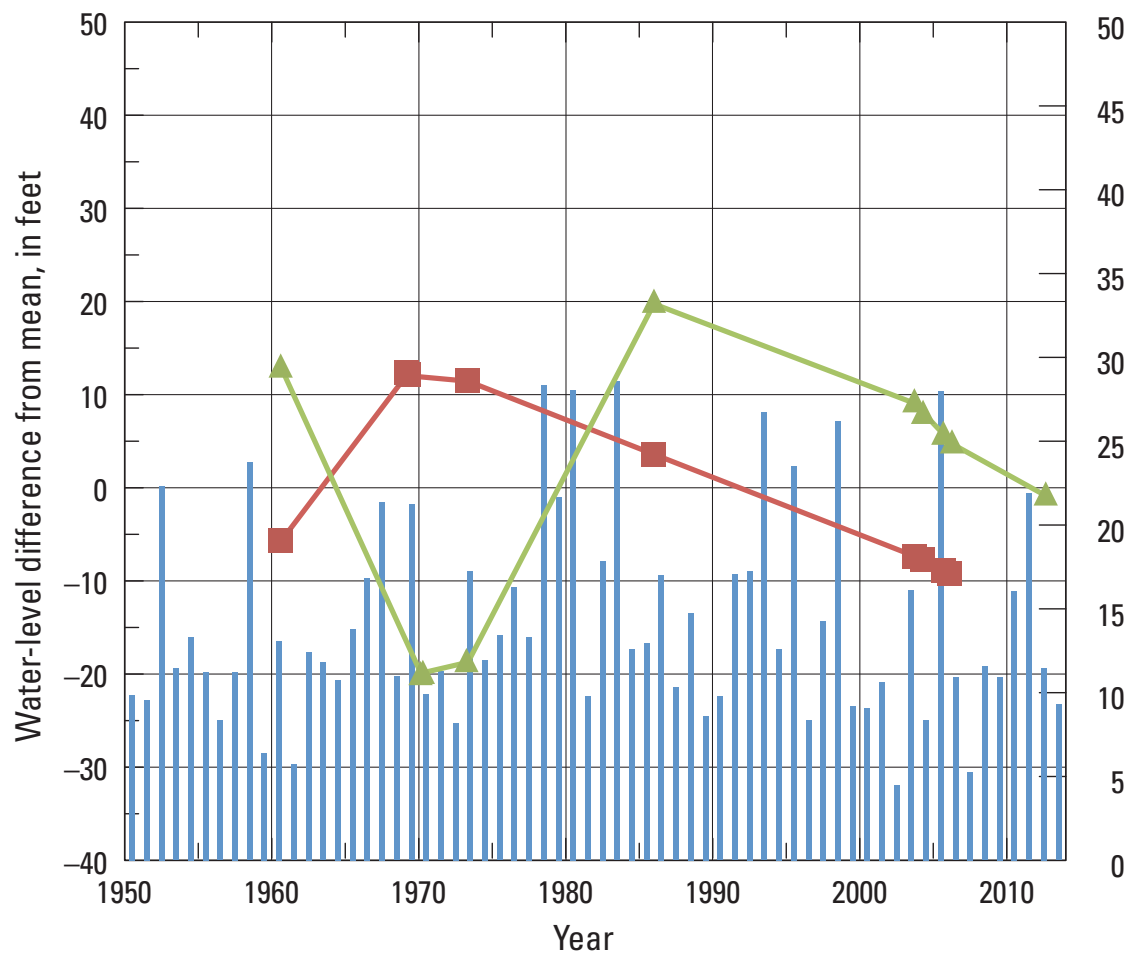

50

45

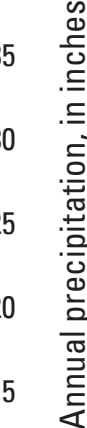

- 7S/3E-9D1 (al)

- 7S/3E-9E1 (Oal)

Precipitation
Well and State well number

$\neg \quad 7 S / 3 \mathrm{E}-11 \mathrm{P} 3$ (0al)

$-\quad 7 \mathrm{~S} / 3 \mathrm{E}-10 \mathrm{~B} 1$ (0al)

$\longrightarrow \quad 7 \mathrm{~S} / 3 \mathrm{E}-13 \mathrm{C} 1$ (BR)

-O- 7S/3E-13D1 (al)

$-\nabla-\quad 7 S / 3 E-14 D 1$ (Oal)

Precipitation

Figure 11. - Continued 
Terwillinger Alluvial Valley

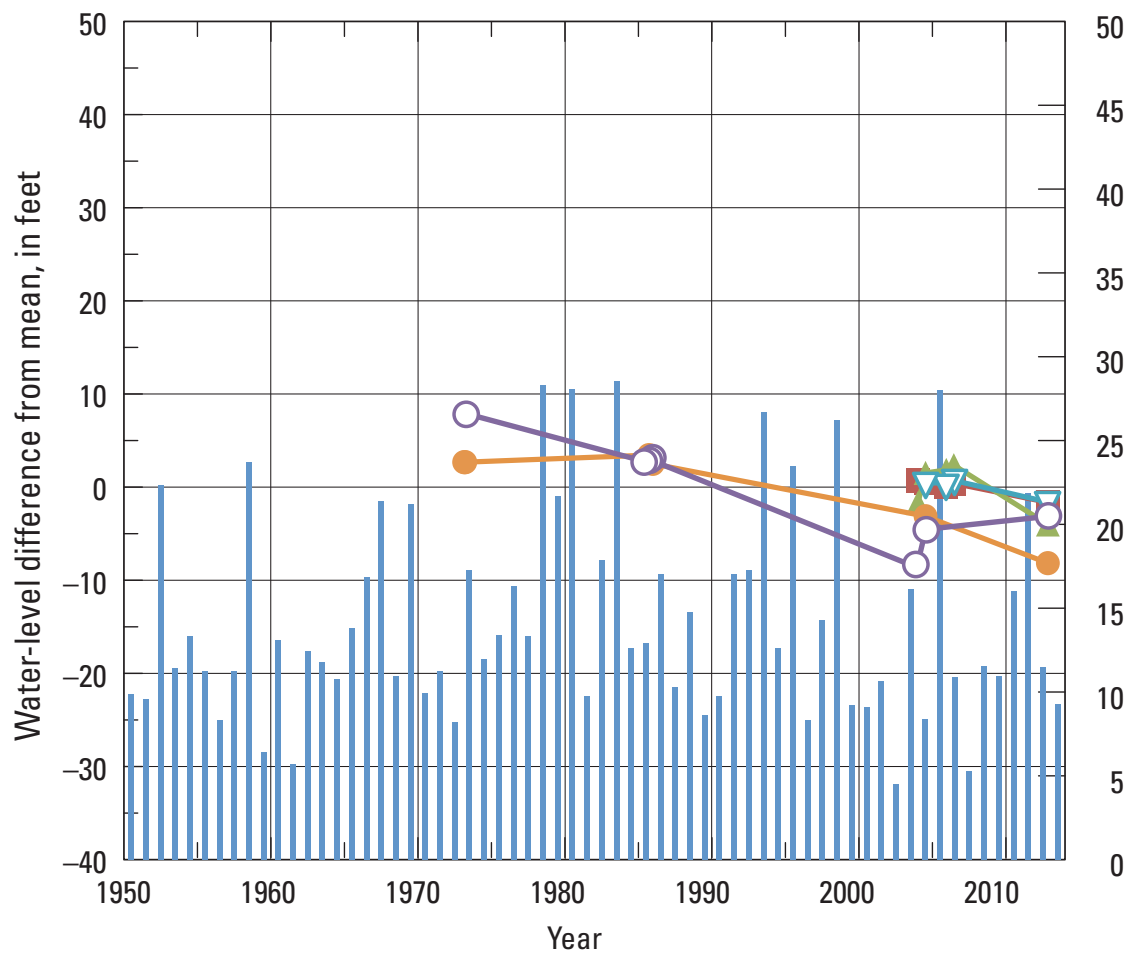

Hard Rock—South

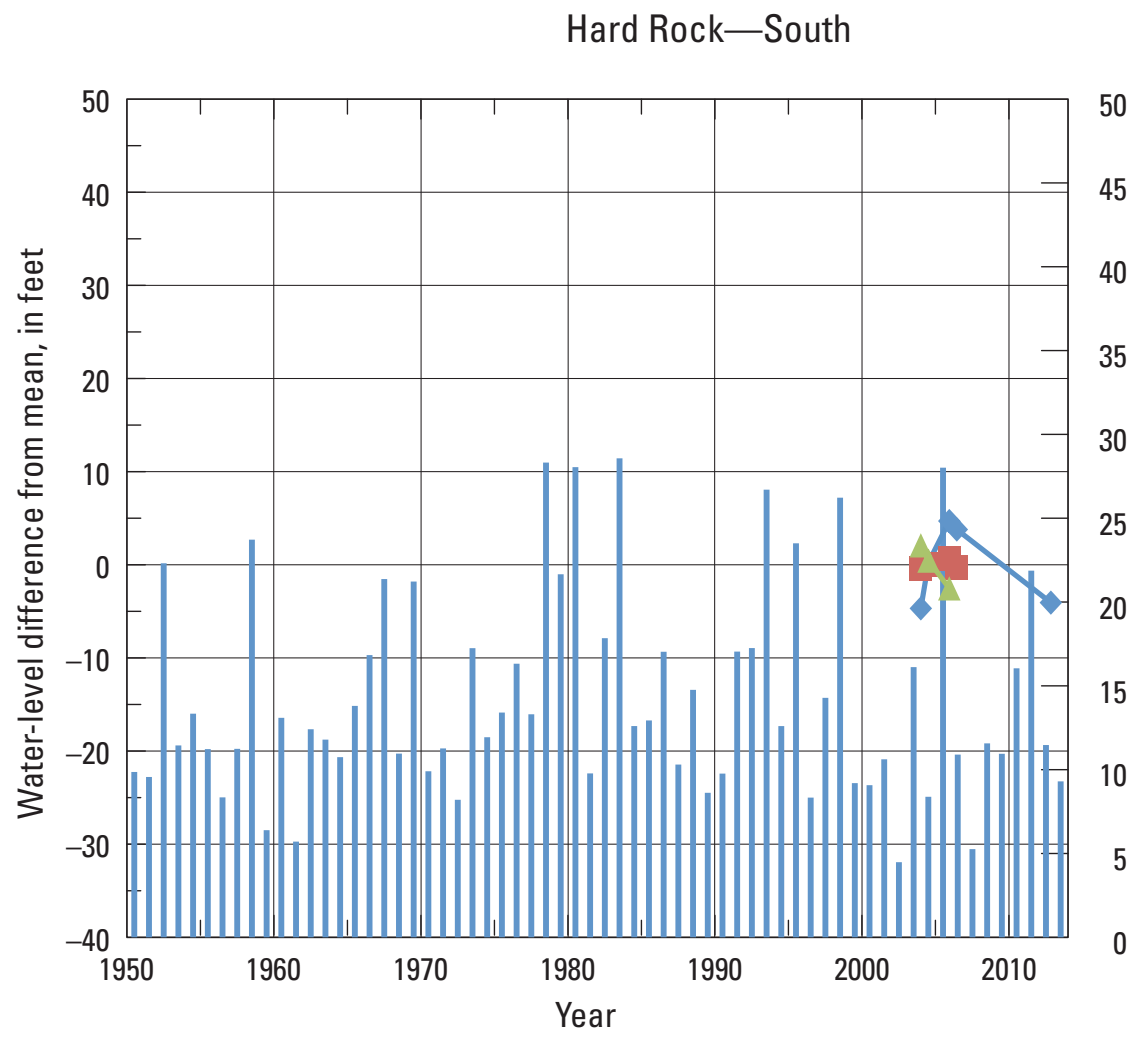

\section{EXPLANATION}

Well and State well number

$\neg$ 8S/3E-14B1 (al)

$\rightarrow$ 8S/3E-14D1 (al)

$\longrightarrow$ 8S/3E-12M2 (al)

$-\nabla-8 \mathrm{~S} / 3 \mathrm{E}-11 \mathrm{M} 1$ (al)

- 8S/4E-7A1 (al)

$+8 \mathrm{~S} / 3 \mathrm{E}-1 \mathrm{~N} 3$ (al) Not plotted

$-0-8 S / 4 E-6 F 5$ (0al/WZ)

Precipitation

$\longrightarrow 8 \mathrm{~S} / 3 \mathrm{E}-17 \mathrm{H} 1$ (BR)

$-8 \mathrm{~S} / 3 \mathrm{E}-9 \mathrm{~F} 1$ (BR)

$-8 \mathrm{~S} / 3 \mathrm{E}-9 \mathrm{H} 1$ (BR)

Precipitation

Figure 11. - Continued 
Anza Basin-West

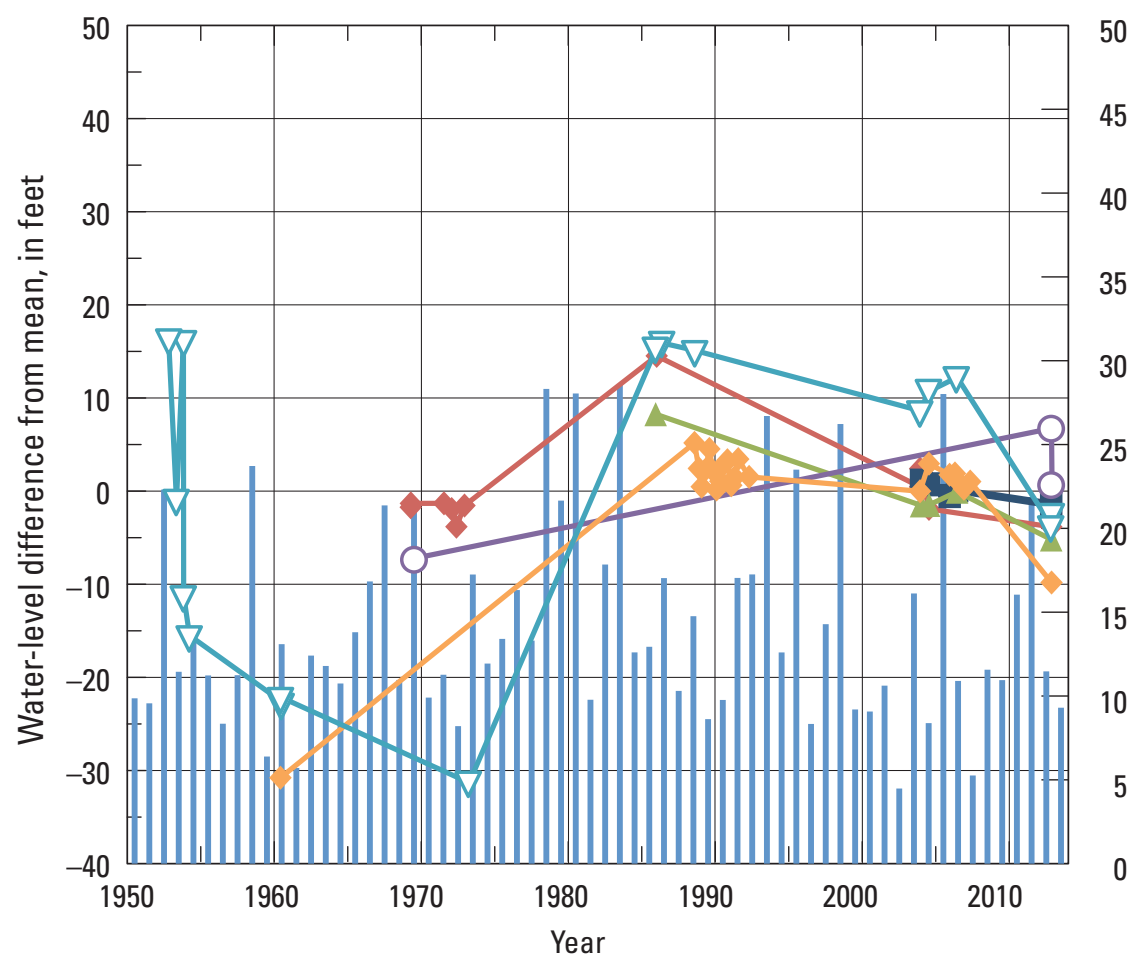

50

45

40

35

30

25

20

15

10

Hard Rock-Central

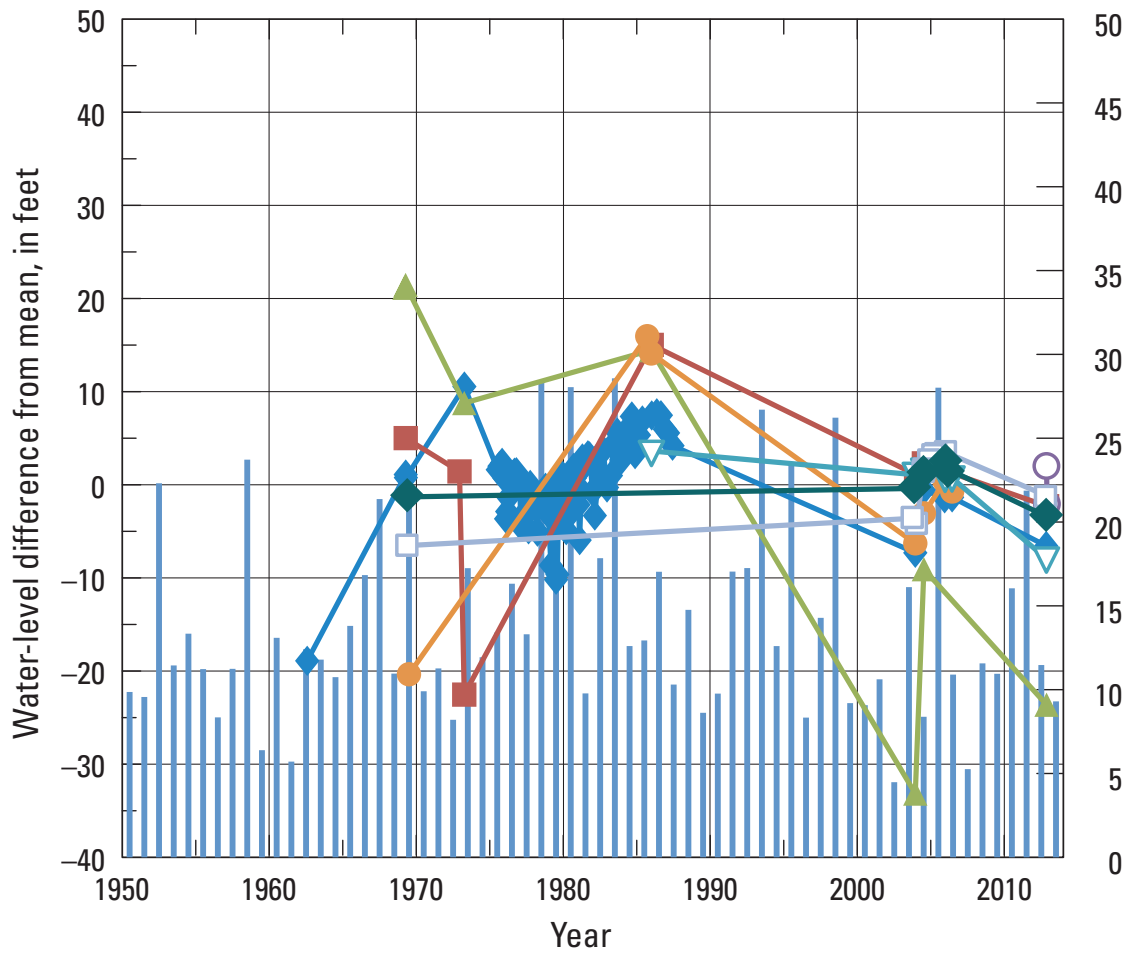

Figure 11. - Continued
50

45

40

35

30

20

15

10

\section{EXPLANATION}

Well and State well number

$\smile \quad 7 S / 3 E-16 N 5$ (al)

$\longrightarrow \quad 7 \mathrm{~S} / 3 \mathrm{E}-17 \mathrm{H} 3$ (al)

- 7S/3E-17H1 (al)

-O 7S/3E-21G1 (al)

$\nabla$ - 7S/3E-21L1 (Oal)

$\longrightarrow \quad 7 \mathrm{~S} / 3 \mathrm{E}-21 \mathrm{L3}$ (Oal)

Precipitation

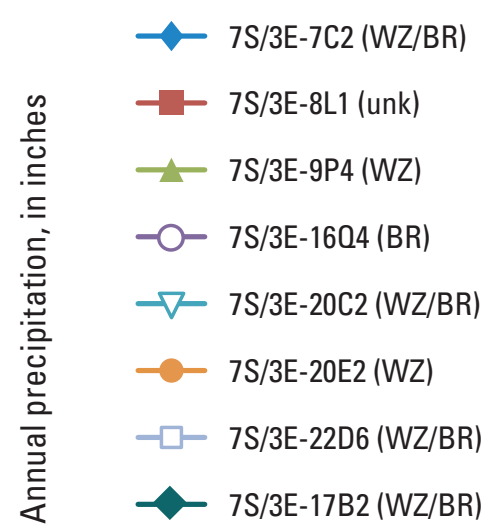

Precipitation 


\section{Summary}

The population of the Anza and Terwilliger area relies solely on groundwater pumped from the alluvial deposits and surrounding bedrock formations for water supply. The size, characteristics, and current conditions of the aquifer system in the Anza-Terwilliger area are poorly understood, however. To understand the characteristics of the aquifer system better, so that water managers in the area can develop groundwater management and monitoring plans, the U.S. Geological Survey cooperated with the High Country Conservancy and Rancho California Water District to do groundwater assessment tasks to advance the state of understanding of the groundwater system of the Anza-Terwilliger area during 2013-14. This work was funded through the California Department of Water Resources (DWR) Integrated Regional Water Management (IRWM) plan for the Santa Margarita River watershed.

The objectives of the Anza-Terwilliger groundwater study were (1) to better define groundwater basin geometry and lithology, (2) to resume groundwater-level monitoring, (3) to collect selected new data to understand vertical variations in water quality better, and (4) to analyze new information in conjunction with previously published information to refine understanding of the groundwater system in the Anza area. The scope of this report includes a description of the study area; methods for collecting and analyzing gravity data to identify the thickness of the alluvial aquifer, for compiling and analyzing aquifer lithology, and for collecting groundwater-level data; and results of analyses to determine alluvial aquifer thickness and basin geometry, aquifer lithology, and changes in groundwater levels from earlier measurements to October-November 2013.

Inversion of gravity data was used to estimate the thickness of the alluvial deposits that form the Cahuilla and Terwilliger groundwater basins and to understand the threedimensional geometry of the basement complex, which underlies the groundwater basins. Gravity measurements were taken at 170 locations in the Anza and Terwilliger area and combined with about 200 regional gravity measurements. After processing and inversion of the data, the thickness of the alluvial aquifer materials was modeled by using all available lithology, density, and geophysical data. The alluvial thickness modeled from the gravity data generally agreed with alluvial thicknesses estimated from more than 900 drillers' logs.

The thickest alluvial deposits are in the northern part of the study area along the south side of the San Jacinto fault zone. Estimated thickness exceeds 1,000 feet in small areas near the fault. Estimated thicknesses greater than 500 feet are widespread in this area. Additional areas having estimated alluvial thicknesses greater than 500 feet are in the southern part of the Cahuilla groundwater basin and the western part of the Terwilliger groundwater basin. Through most of the area of alluvial materials, the thickness of the alluvium estimated from gravity data is less than 400 feet.

Analysis of more than 900 drillers' logs in the study area indicated that the fractured basement rocks are an important source of groundwater, primarily for domestic use. On the basis of the available logs, many more wells have been drilled into fractured bedrock than alluvium in the study area. The depths of penetration into the bedrock of many wells, up to several hundred feet, indicated that fractures potentially supplying water to wells persist to a considerable depth and that the permeable zone of the fractured bedrock extends through the weathered part of the bedrock into competent rock. The proximity and co-location of holes with alluvium only, bedrock only, and alluvium overlying bedrock in areas, such as the northern Anza Valley, indicated that the basement rocks and alluvium both are important sources of water supply in some areas and could serve as a connected aquifer system.

The alluvium is predominantly composed of sand and gravel with interbedded discontinuous finer-textured silts and clays. In areas of relatively large thickness of alluvial sediments, particularly along the San Jacinto fault zone and in the Terwilliger Valley, the alluvium is predominantly composed of sands and gravels. In the area south of the San Jacinto fault zone, fine-textured sediments primarily are in the middle to deeper part of the alluvial sediments. The extent to which these discontinuous clayey zones could serve as confining units is unknown because of the lack of water-level data from short-screened wells perforated above and below those fine-textured zones. In the area of relatively thick alluvium in the Terwilliger Valley, the alluvium is predominantly composed of sand; where the alluvium thins, interbedded clay and sand are predominant. Although data were sparse, sediments in the thinner alluvial deposits between the boundaries of the Cahuilla and Terwilliger groundwater basins appeared to be relatively fine textured. The thin and fine-textured deposits have the potential to limit groundwater fluxes across the boundary between the Terwilliger and Cahuilla groundwater basins.

Water-level data were collected from 59 wells during fall 2013; these data were compared to water levels measured in fall 2006 and fall 2004 in most of these wells. The limited data indicated that hydraulic head did not vary much with depth and that the measured water levels were similar both in consolidated rocks and alluvium. Large offsets in groundwater altitude across the San Jacinto fault zone indicated that the fault is a barrier to groundwater flow in the northeastern part of the Anza Valley. Water-level altitudes on the east side of the fault were hundreds of feet higher than on the west. 
Water-level measurements in 33 wells showed that watertable altitudes mostly declined between the fall of 2006 and the fall of 2013, having a median decline of 5.1 feet during this period, or a median rate of decline of 0.73 feet/year. Water-level measurements in 40 wells showed that changes in water-table altitude between the fall of 2004 and the fall of 2013 were more variable than between 2006 and 2013, but the median change was a decline of 2.4 feet, or a median rate of decline of 0.27 feet/year. Thus, the apparent rate of groundwater level decline from 2004 to 2013 was less than from 2006 to 2013 . The difference in the magnitude of groundwater declines over these two periods reflected conditions that were wetter preceding fall 2006 measurements than those preceding the fall 2004 measurements. These fluctuations in rates of groundwater-level change highlight the value of ongoing water-level measurements to distinguish long-term (decadal or longer) trends from fluctuations associated with short-term climatic variability.

Fifty-four hydrographs were plotted to allow viewing of long-term and short-term water-level changes across the study area. The hydrographs indicated the sensitivity of the groundwater levels to climatic conditions, but also generally showed a decline in water levels across the study area since 1986 and, in some cases, dating back to the onset of data collection in the 1950s. In the cases of the Anza and Terwilliger Valleys, little variation in long-term water-level changes were observed between alluvial and fractured granitic and metasedimentary rocks (with the exception of those bounded by faults), indicating the units are hydraulically connected.

\section{References Cited}

Baranov, V., 1957, A new method for interpretation of aeromagnetic maps; pseudo-gravimetric anomalies: Geophysics, v. 22, No. 2, p. 359-383, http://dx.doi.org/10.1190/1.1438369.

Biehler, Shawn, Langenheim, V.E., Sikora, R.F., Chapman, R.H., and Beyer, L.A., 1992, Complete Bouguer gravity anomaly map of the Santa Ana 1 degree by 2 degrees quadrangle, California: U.S. Geological Survey, Open-File Report 92-279, scale 1:250,000,

http://pubs.er.usgs.gov/publication/ofr92279.

Binder, C.W., 2012, Santa Margarita River watershed annual watermaster report, water year 2010-11, United States of America v. Fallbrook Public Utility District, et al., Civil No. 51-CV-1247-LAB-RBB, 105 p., 6 appendices.
Burow, K.R., Shelton, J.L., Hevesi, J.A., and Weissmann, G.S., 2004, Hydrogeologic characterization of the Modesto Area, San Joaquin Valley, California: U.S. Geological Survey Scientific Investigations Report 2004-5232, 54 p., http://pubs.er.usgs.gov/publication/sir20045232.

California Department of Water Resources, 2004a, California's groundwater-individual basin descriptions, Cahuilla Valley groundwater basin: California Department of Water Resources Bulletin 118, accessed August 12, 2013, at http://www.water.ca.gov/pubs/groundwater/bulletin_118/ basindescriptions/9-6.pdf.

California Department of Water Resources, 2004b, California's groundwater-individual basin descriptions, Terwilliger Valley groundwater basin: California Department of Water Resources Bulletin 118, accessed August 12, 2013, at http:/www.water.ca.gov/pubs/ groundwater/bulletin_118/basindescriptions/7-26.pdf.

California Department of Water Resources, 2007, 2000 Riverside County land use survey data: accessed August 12, 2013, at http://www.water.ca.gov/landwateruse/lusrvymain.cfm.

Cunningham, W.L., and Schalk, C.W., comps., 2011, Groundwater technical procedures of the U.S. Geological Survey: U.S. Geological Survey Techniques and Methods 1-A1, 151 p., http://pubs.er.usgs.gov/publication/tm1A1.

Dibblee, T.W., and Minch, J.A., 2008, Geologic map of the Hemet and Idyllwild 15 minute quadrangles, Riverside County, California: Dibblee Geological Foundation, Dibblee Foundation Map DF-371, scale 1:62,500.

Dor, Ory, Rockwell, T.K., and Ben-Zion, Yehuda, 2006, Geological observations of damage asymmetry in the structure of the San Jacinto, San Andreas, and Punchbowl Faults in Southern California: a possible indicator for preferred rupture propagation direction: Pure and Applied Geophysics, v. 163, p. 301-349, http://dx.doi.org/10.1007/s00024-005-0023-9.

Faunt, C.C., ed., 2009, Groundwater availability of the Central Valley Aquifer, California: U.S. Geological Survey Professional Paper 1766, 225 p., http://pubs.er.usgs.gov/publication/pp1766.

Faunt, C.C., Belitz, Kenneth, and Hanson, R.T., 2010, Development of a three-dimensional model of sedimentary texture in valley-fill deposits of Central Valley, California, USA: Hydrogeology Journal, v. 18, p. 625-649, http://dx.doi.org/10.1007/s10040-009-0539-7. 
Flint, L.E., Flint, A.L, Thorne, J.H., and Boynton, Ryan, 2013 Fine-scale hydrologic modeling for regional landscape applications: the California Basin Characterization Model development and performance: Ecological Processes, v. 2, No. 25, 21 p., http://dx.doi.org/10.1186/2192-1709-2-25.

Jachens, R.C., 1992, Aeromagnetic map of the Palm Springs 1:100,000 scale quadrangle, California: U.S. Geological Survey, Open-File Report 92-549, scale 1:100,000, http://pubs.er.usgs.gov/publication/ofr92549.

Jachens, R.C., 1993, Aeromagnetic map of the Borrego Valley 1:100,000 scale quadrangle, California: U.S. Geological Survey, Open-File Report 93-283, scale 1:100,000, http://pubs.er.usgs.gov/publication/ofr93283.

Jachens, R.C., and Moring, B.C., 1990, Maps of the thickness of Cenozoic deposits and the isostatic residual gravity over basement for Nevada: U.S. Geological Survey Open-File Report 90-404, 15 p., 2 pls. http://pubs.er.usgs.gov/publication/ofr90404.

Landcaster, J.T., Hayhurst, C.A., and Bedrossian, T.L., 2012, Preliminary geologic map of quaternary surficial deposits in Southern California: Palm Springs 30' X 60' Quadrangle, California Geological Survey Special Report 217, pl. 24, accessed November 13, 2013, at http://www.consrv.ca.gov/ cgs/fwgp/Documents/plate24_palm_springs.pdf.

Langenheim, V.E., and Jachens, R.C., 1993, Isostatic residual gravity map of the Borrego Valley 1:100,000 quadrangle, California: U.S. Geological Survey Open-File Report 93-246, scale 1:100,000, http://pubs.er.usgs.gov/publication/ofr93246.

Londquist, C.J., and Martin, P.R., 1991, Geohydrology and ground-water-flow simulation of the Surprise Spring Basin aquifer system, San Bernardino County, California: U.S. Geological Survey Water-Resources Investigations Report 89-4099, 41 p., http://pubs.er.usgs.gov/publication/wri894099.

Martin, Peter, ed., with contributions by Brandt, Justin, Catchings, R.D., Christensen, A.H., Flint, A.L., Gandhok, Gini, Goldman, M.R., Halford, K.J., Langenheim, V.E., Martin, Peter, Rymer, M.J., Schroeder, R.A., Smith, G.A., and Sneed, Michelle, 2011, The source, discharge, and chemical characteristics of water from Agua Caliente Spring, Palm Springs, California: U.S. Geological Survey Scientific Investigations Report 2011-5156, 106 p., http://pubs.er.usgs.gov/publication/sir20115156.
Matti, J.C., and Morton, D.M., 1993, Paleogeographic evolution of the San Andreas Fault in southern California: A reconstruction based on a new cross-fault correlation, chap. 2 in Powell, R.E., Weldon, R.J., II, and Matti, J.C., eds., The San Andreas fault system: Displacement, palinspastic reconstruction, and geologic evolution: Boulder, Colorado, Geological Society of America Memoirs, v. 178, p. 107-160, http://dx.doi.org/10.1130/MEM178-p107.

Morita, A.Y., Clark, D.A., and Martin, Peter, 2007a, AnzaTerwilliger hydrogeologic structures in Riverside County, California: U.S. Geological Survey Unnumbered Series at http://pubs.er.usgs.gov/publication/70046028.

Morita, A.Y., Clark, D.A., and Martin, Peter, 2007b, AnzaTerwilliger study wells in Riverside County, California: U.S. Geological Survey Unnumbered Series at http://pubs.er.usgs.gov/publication/70046035.

Morton, R.A., Leach, M.P., Paine, J.G., and Cardoza, M.A., 1993, Monitoring beach changes using GPS surveying techniques: Journal of Coastal Research, v. 9, no. 3, p. 702720, http://www.jstor.org/stable/4298124.

Moyle, W.R., Jr., 1976, Geohydrology of the Anza-Terwilliger area, Riverside County, California: U.S. Geological Survey Water-Resources Investigations Report 76-10, 25 p., http://pubs.er.usgs.gov/publication/wri7610.

Ponce, D.A., and Langenheim, V.E., 1992, Isostatic residual gravity map of the Palm Springs 1:100,000-scale quadrangle, California: U.S. Geological Survey OpenFile Report 92-702, scale 1:100,000, http://pubs.er.usgs.gov/publication/ofr92702.

Roberts, C.W., and Jachens, R.C., 1986, High-precision gravity stations for monitoring vertical crustal motion in southern California: U.S. Geological Survey Open-File Report 86-44, 76 p., http://pubs.er.usgs.gov/publication/ofr8644.

Rogers, T.H., 1965, Geologic map of California: Santa Ana sheet: California Division of Mines and Geology, scale $1: 250,000$.

Rydlund, P.H., Jr., and Densmore, B.K., 2012, Methods of practice and guidelines for using survey-grade global navigation satellite systems (GNSS) to establish vertical datum in the United States Geological Survey: U.S. Geological Survey Techniques and Methods 11-D1, 102 p., http://pubs.er.usgs.gov/publication/tm11D1. 
Sweetkind, D.S., Faunt, C.C., and Hanson, R.T., 2013, Construction of 3-D geologic framework and textural models for Cuyama Valley groundwater basin, California: U.S. Geological Survey Scientific Investigations Report 2013-5127, 46 p., http://pubs.er.usgs.gov/publication/sir20135127.

Telford, W.M., Geldart, L.O., Sheriff, R.E., and Keyes, D.A., 1976, Applied Geophysics: New York, Cambridge University Press, 960 p.

U.S. Census Bureau, 2013, 2010 Demographic Profile, Anza, California: accessed August 12, 2013, at http://www.census.gov/popfinder/?fl=0602294.

Western Regional Climate Center, 2013, Anza California, National Climatic Data Center 1981-2010 Monthly Normals, accessed August 12, 2013, at http://www.wrcc.dri.edu/cgi-bin/cliMAIN.pl?ca0235.

Woolfenden, L.R., and Bright, D.J., 1988, Ground-water conditions in the Anza-Terwilliger area, with emphasis on the Cahuilla Indian Reservation, Riverside County, California, 1973-86: U.S. Geological Survey WaterResources Investigations Report 88-4029, 79 p., scale 1:77,000, http://pubs.er.usgs.gov/publication/wri884029. 
The following Appendices are supplied in a downloadable Microscoft Excel $^{\circledR}$ file:

\section{Appendix 1: Identification and}

Construction Information for Selected

Wells in the Anza-Terwilliger Area,

Riverside County, California.

Appendix 2: Historical Water Levels in the Anza-Terwilliger Area, Riverside County, California.

\section{Appendix 3: Fall 2013 Water Levels in the Anza-Terwilliger Area, Riverside County, California.}
Appendix 4: Change in Water Level Altitude in Fall 2013, 2006, and 2004 in the Anza-Terwilliger Area, Riverside County, California. 
Prepared by the Sacramento Publishing Service Center.

For more information concerning this report, contact:

Director

U.S. Geological Survey

California Water Science Center

6000 J Street, Placer Hall

Sacramento, CA 95819

dc_ca@usgs.gov

or visit our Web site at:

http://ca.water.usgs.gov 


\section{$\frac{\mathbb{2}}{3}$}

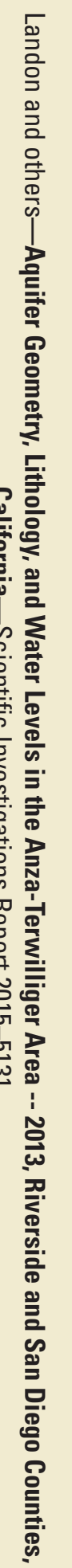

